\title{
Radiocarbon chronology of the Neolithic-Eneolithic period in the Karelian Republic (Russia)
}

\author{
Aleksey Tarasov ${ }^{1}$, Kerkko Nordqvist ${ }^{2}$, Teemu Mökkönen ${ }^{2}$ and Tatyana Khoroshun ${ }^{1}$ \\ 1 Department of Archaeology, Institute of Linguistics, Literature and History of the Karelian Research Centre, \\ Russian Academy of Sciences, Karelian Republic, Petrozavodsk, RU \\ taleksej@drevlanka.ru; tattya@list.ru \\ 2 Archaeology, University of Oulu, Oulu, FI \\ kerkko.nordqvist@gmail.com; teemu.mokkonen@gmail.com
}

\begin{abstract}
This article discusses a radiocarbon-based chronology for the Neolithic-Eneolithic period in the present-day Republic of Karelia (Russian Federation). The main goal is to present all currently available radiocarbon datings, including the previously published dates, as well as the ones recently obtained by the authors. In total, there are 194 dates from 77 sites covering the period from the $6^{\text {th }}$ to the $2^{\text {nd }}$ millennium cal BC. Besides providing an up-to-date list of datings, the article also evaluates their reliability and utility in building a local chronology. Despite several shortcomings, the new AMS-supported chronology enables the study of past cultural dynamics in much greater detail than previously and allows its better integration into the wider north-east European chronological framework.
\end{abstract}

KEY WORDS - Neolithic; Eneolithic; radiocarbon chronology; pottery; Karelian Republic

\section{Radiokarbonska kronologija neolitika - eneolitika v Republiki Kareliji (Rusija)}

\begin{abstract}
IZVLEČEK - V članku razpravljamo o radiokarbonski kronologiji obdobij neolitika-eneolitika $v$ današnji Republiki Kareliji (Ruska federacija). Predstaviti želimo vse razpoložljive datume, tako tiste že objavljene kot tudi najnovejše datume, ki smo jih pridobili avtorji. Skupno je sedaj na voljo 194 datumov iz 77 najdišč, ki pokrivajo čas od 6. do 2. tisočletja pr. n. št. Poleg novega seznama vseh radiokarbonskih datumov ocenjujemo v članku tudi zanesljivost in koristnost le-teh za oblikovanje lokalne kronologije. Kljub številnim pomanjkljivostim omogoča nova kronologija, ki temelji na AMS radiokarbonskih datumih, veliko bolj natančne študije preteklih kulturnih dinamik, kot je bilo to možno v preteklosti, ter omogoča boljšo integracijo v kronološke okvirje na širšem območju severovzhodne Evrope.
\end{abstract}

KLJUČNE BESEDE - neolitik; eneolitik; radiokarbonska kronologija; lončenina; Republika Karelija

\section{Introduction}

\begin{abstract}
Aims
This paper presents all radiocarbon dates obtained from the Neolithic and Eneolithic sites (see below) in the present-day Karelian Republic, Russian Federation, and outlines the chronological position of the main groups of archaeological material (i.e. pottery
\end{abstract}

types) known in this territory between the $6^{\text {th }}$ and $2^{\text {nd }}$ millennia cal BC. The current paper is a combination of two articles recently published in Russian: the first one providing a discussion of datings available prior to 2016 (Tarasov, Khoroshun 2016) and the second one presenting an AMS-based chronology 
for the Karelian Neolithic through introduction of 41 new dates (Nordqvist, Mökkönen 2017a; see also Nordqvist, Mökkönen 2016a; 2016b).

Most of the previous discussions of radiocarbon dates from Karelia have been in Russian (Kochkurkina 1991; German 2002; 2012; Kosmenko 2003; Lobanova 2004; Vitenkova 2009; Piezonka 2011; Mel'nikov, German 2013; Khoroshun 2015; but see Kosmenko 2004; Piezonka 2008; 2015; Zhulnikov et al. 2012). An overview of the chronology and periodisation of Karelia published in 1991 comprised a total of 112 conventional radiocarbon determinations from the Mesolithic Stone Age to the Early Middle Ages (Kochkurkina 1991), and a special publication devoted to the Neolithic chronology of eastern Europe discussed Karelia some 10 years later and contained 72 dates listed as Neolithic (Timofeev et al. 2004; see also Kosmenko 2004). These publications are now out of date, since quite a few AMS dates have been produced in recent years (e.g., Lobanova 2004; Piezonka 2008; Nordqvist, Mökkönen 2017a). At the moment, 170 radiocarbon datings with a more or less clear connection to the Neolithic and Eneolithic periods have been ob-

Map 1. Location of sites with radiocarbon dates in the territory of $\mathrm{Ka}$ relian Republic (Russian Federation: 1 Uya III; 2 Pegrema I-III, IX, Palayguba II, X; 3 Sulgu II, Lakshozero II, Kudoma X; 4 Vozhmarikha 1, 4, 19, 21, 26, Bukol'nikov 1, Vorob'i 4; 5 Panozero I; 6 Kalmozero II; 7 Shettima I; 8 Sheltozero V, X-XII; 9 Orovnavolok V, VII, XI, XVI, Chernaya Guba III-IV, IX, Myan'gora I; 10 Chernaya Rechka I, II, IIa, XII, Kladovets IV, Va, IX, Kladovets (cemetery); 11 Yerpin Pudas I, Zalavruga I, IV, Zolotets VI, X, XI, XX, Besovy Sledki, Besovy Sledki II; 12 Vigaynavolok I-II; 13 Sukhaya Vodla I; 14 Voynavolok XXIV, XXVII, XXIX, Kochnavolok II, Povenchanka XV; 15 Fofanovo XIII; 16 Berezovo XVII, Tunguda III, XIV, XV, XVII; 17 Meyeri II; 18 Kudomguba VII; 19 Chelmuzhskaya Kosa XXI; 20 Kostomuksha II; 21 Pinguba II; 22 Suna XII; 23 Keret' XXII; 24 Pervomayskaya I; 25 Sumozero XV; 26 Koyrinoya 2, 3; 27 Kurkieki 52 (Kuuppala Kalmistomäki), Kurkieki 33 (Kylliäisenlahti W-2) (map created by A. Tarasov). tained from Karelia; in addition, 24 datings have been presented in this context, even if their connection to the periods in question remains equivocal (see below).

Recently-obtained AMS dates have considerably refined the Neolithic chronology in Karelia. This paper is an attempt to compile all the available data and discuss the present state of affairs. The purpose is not to present the final word on the topic, as the number and quality of dates in many cases is still low and there are many ambiguities and problems, as will be shown below. Even if the main focus is on presenting the Karelian material, the chronology is also compared with corresponding chronologies in neighbouring regions, particularly Finland.

The dates that form the basis of this paper are listed in the tables. Table 1 presents the dates which ge-

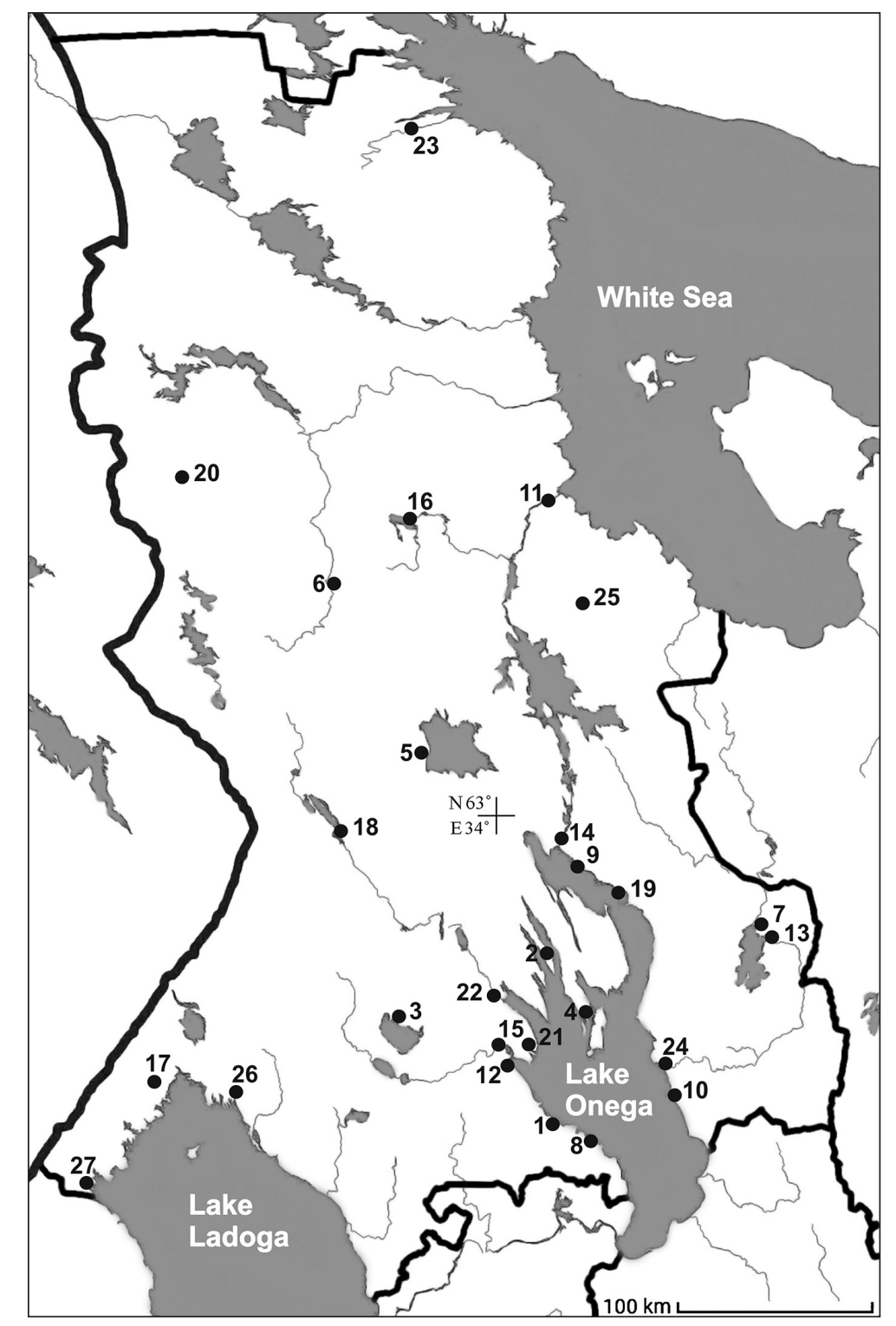


nerally correspond with archaeological materials present at the sites. In cases where a sample's connection with particular archaeological materials is unequivocal (e.g., crusts on pottery shards), only this pottery type is mentioned (column 'Typological connection') even if the site contained material from other phases, too. However, if such a clear connection cannot be established, all assemblages present at the site are listed. Table 2 presents dates that do not correspond with any archaeological materials found at these sites. It includes Neolithic/Enolithic dates from sites with no finds from this period or datings from sites with Neolithic/Eneolithic material, but with significantly deviatory (younger) ages. The dates given in Table 2 are not included in the discussion below. The geographical locations of the sites are marked on Map 1. All dates have been calibrated with 0xCal v. 4.2 (Bronk Ramsey 2009) and the calibration curve IntCal13 (Reimer et al. 2013); in the text, they are given either as median values or with $2 \sigma$ standard deviation.

\section{Periodisation}

The Neolithic finds of Karelia have been traditionally divided into temporal units - archaeological cultures - primarily on the basis of pottery (see Kochkurkina 1991; Kochkurkina, Kosmenko 1990). These types coincide with ceramic types recognised in neighbouring territories, especially Finland, although the periodisation schemes used in these areas are quite different, mainly due to differing research traditions (also Nordqvist 2013; Nordqvist, Mökkönen $2017 c$ ). According to the periodisation applied to Karelia, the Early Neolithic is represented by Sperrings and Säräisniemi 1 Wares, the mid-part of the period by Pit-Comb Ware, and the Late Neolithic by Comb-Pit Ware. The subsequent phases with RhombPit Ware and ceramics with asbestos and organic tempers are traditionally considered to belong already to another period, the Eneolithic, which has been separated because of small-scale exploitation of native copper originating on the western shores of Lake Onega.

The separation of the Eneolithic introduces some inconsistencies into the periodisation. As will be shown later, sites with Comb-Pit and Rhomb-Pit Wares were, in fact, largely coeval and share fairly similar material cultures and cultural images. Nevertheless, only sites with Rhomb-Pit Ware are traditionally regarded as Eneolithic, whereas sites with Comb-Pit Ware are still Neolithic, as no copper items have been found at 'pure' Comb-Pit Ware sites in Karelia. However, individual copper objects (predominantly amorphous pieces) have been discovered in Comb-Pit Ware (i.e. Typical Comb Ware) contexts in Finland and northern Sweden (see Nordqvist, Herva 2013). To solve the problem, A. M. Zhul'nikov (1999) has suggested that only sites with asbestos- and organic-tempered pottery should be regarded as Eneolithic, as during this time the thermal treatment of copper (including melting and casting) became known; at sites with Rhomb-Pit Ware (and Typical Comb Ware) only evidence of cold hammering and annealing exists (Zhul'nikov 1999.66; see Ikäheimo, Pääkkönen 2009; Ikäheimo, Nordqvist 2017 for Finland). Still, the total amount of copper items remained small and the metal did not change the general cultural image in any significant way. Therefore, the initial adoption of copper should be seen just as another example of a growing interest in the mineral world in general during the Neolithic, not a sign of a separate period (Nordqvist, Herva 2013.424; Herva et al. 2014; 2017).

Because of the controversies associated with the Eneolithic period in Karelia, the dates connected with Rhomb-Pit Ware and asbestos- and organic-tempered pottery are included in this paper as well. In other words, the period covered, from the (later) $6^{\text {th }}$ to the (earlier) $2^{\text {nd }}$ millennia cal $\mathrm{BC}$, is equivalent to the Neolithic and the Eneolithic (or the Neolithic and the earlier part of Early Metal Period) according to traditional Karelian periodisation (Fig. 1).

\section{Overview of Karelian radiocarbon data}

\section{Context datings}

Most Karelian radiocarbon dates (114) are context dates, mostly processed on charcoal and originating in cultural layers and different features (pits, fireplaces, dwelling constructions) of settlement sites. The reliability of these dates is seriously questioned by the fact that the majority of settlement sites in Karelia are multi-component, non-stratified locations, which contain material from several habitation episodes whose typological dating may span several millennia. This situation is explained by the geological and hydrological settings and the Stone Age and Early Metal Period economy: the groups of fisher-hunter-gatherers preferred to settle near water, which in the Karelian situation meant living mainly on lake shore terraces. As the shorelines of the majority of Karelian lakes remained fairly stable during the Holocene, areas suitable for settling remained almost the same up to the present time. This is characteristic even of such a large lake as Lake Onega, where numerous regressions and transgres- 
sions took place, but affected parts of its coasts in different ways (e.g., Devyatova 1986; Saarnisto, Vuorela 2007).

Due to mixed multi-component assemblages, as well as the rough excavation and documentation methods employed, especially earlier, in most cases it is not possible to establish an unequivocal connection between a charcoal sample and particular archaeological materials identified at a site. This is evident in the case of charcoals collected from the cultural layer, but even in the case of samples originating in fireplace-like or other features it is not possible to fully exclude the possibility of forest fires or other post-depositional contamination.

The old-wood effect might also affect dates processed on charcoal from clear structures, such as dwelling remains. Because tree species and the origins (branch, trunk) of dated charcoals have not been determined, further estimating its presence and magnitude is not possible. As the log-based houses were made with stone tools, the timbers used to build them are unlikely to have been dry deadwood or thick live trunks with significant age. However, repairing and reuse may have introduced material of different ages into the houses and, again, later (natural) mixing cannot be ruled out. Thus, even if the dates from burnt constructions (walls) of dwellings are likely linked to human activities and even if they may be considered as the most reliable charcoal context dates, especially at single-component sites, they may yield widely varying ages. This is well illustrated by dwelling 1 at the Sumozero XV site (Zhul'nikov 2005.85-88): seven samples of charcoal and birch bark were taken from a burnt house construction (Tab. 1), but the determinations spread over

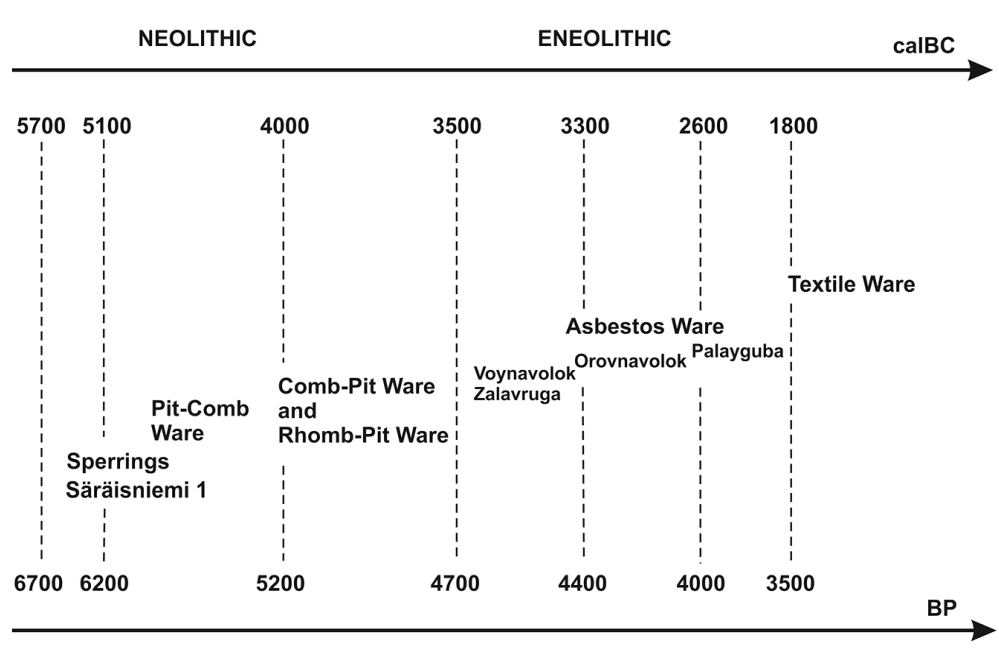

Fig. 1. Simplified chronology of the leading Neolithic and Eneolithic ceramic types in Karelia (designed by A. Tarasov). half a millennium, at the minimum. All in all, the number of dates from dwellings is not very big: 35 dates in total ( 21 from burnt walls), most deriving from Late Neolithic/Eneolithic contexts.

\section{Datings of charred residues and burnt bones}

The introduction of the AMS technique has revolutionised dating and local chronologies in many fields. However, in Karelia the number of AMS dates has risen only in recent years (see Nordqvist, Mökkönen 2017a). At the moment, there are 60 AMS determinations related to pottery ( 44 charred residue/ food crust, 14 birchbark tar, one paint-like substance, one unknown) and seven dates of bone (six of them burnt). In addition, 13 dates of charred crusts established by conventional method exist.

The dated samples are clearly of anthropogenic origin, and their archaeological context is usually unquestionable, although in the case of bones, the connection with specific archaeological phenomena may remain uncertain at multi-component sites. Also, sampling and laboratory-related issues, contamination by (younger) organics (which may affect all other types of samples as well), and the influence of the (freshwater) reservoir effect may reduce the accuracy of the dates.

The reservoir effect has been intensively studied recently on the basis of archaeological and experimental materials (e.g., Fischer, Heinemeier 2003; Olsen et al. 2010; Philippsen, Heinemeier 2013; Kulkova et al. 2015; Philippsen 2015). In Karelia, the existence of the freshwater reservoir effect was hypothesised in connection with Late Neolithic/Eneolithic asbestos- and organic-tempered wares, and it was proposed that the crust dates are mainly affected by the freshwater reservoir effect, as they tend to date somewhat older than charcoal dates (Zhulnikov et al. 2012). However, this tendency remains speculative, as the study contained almost no comparable AMS or conventional datings from the same sites, not to mention the same contexts (see also Nordqvist, Mökkönen $2017 a)$.

The differences between AMS dates and conventional dates connected with the same cultural phases vary from zero up to 500-600 ${ }^{14} \mathrm{C}$-years or even more. It is not possible to say that AMS dates would always be 
older than context dates - it may also be the other way round - and the results also highlight the inconsistency of context dates at several locations. At many sites, AMS dates are spread over 50-200 ${ }^{14} \mathrm{C}$-years: currently, it is not possible to decide whether this is due to prolonged or recurrent use of the locations, or to limitations in measurement accuracy, the properties of calibration curves, or reservoir effects.

One way to control for the presence of the (freshwater) reservoir effect has been the study of bulk stable isotopes. Even if this provides a rather crude tool compared to the more sophisticated analyses of compound-specific values, they are nevertheless thought to allow some level of estimate of the components included in the dated samples. Unfortunately, isotopic data are scarce, and only $\delta^{13} \mathrm{C}$ values have been published for the recently-obtained AMS dates: they range between $-24 \%$ and $-30 \%$, the average being $-27.5 \%$ (see Nordqvist, Mökkönen $2017 a$ ). In previous studies the boundary between residues of marine and terrestrial/freshwater origin is often set at $-26 \%$ (Fischer, Heinemeier 2003. 460). As most Karelian dates have values below this, they could be expected to include terrestrial and/or freshwater components, also hinted at by the sites' location beside lakes and rivers. Still, the values are on average fairly moderate. The only dates with a marine component have been obtained from sites located in the White Sea area, but none of these give obviously divergent results.

The magnitude of the (freshwater) reservoir effect in north-eastern Europe, low on natural limestone, has been considered fairly small (Pesonen et al. 2012. 665), but the topic has not been specifically studied. It was proposed recently that low alkalinity of water does not automatically mean that the freshwater reservoir offset would not be present, as other factors such as the depth of basins, prolonged ice coverage and glacial meltwaters may have contributed to the phenomenon (Philippsen 2015.160). In northern central Europe, southern Scandinavia and south-eastern Baltic, the estimates and measured results of the (freshwater) reservoir offset range from some centuries to thousands of years (e.g., Fischer, Heinemeier 2003.461; Olsen et al. 2010.640; Hartz et al. 2012. 1041; Philippsen, Heinemeier 2013.1098; Piličiauskas, Heron 2015.539). Nevertheless, these results cannot be directly applied to Karelian material, as the magnitude is strongly dependent on the geographical location and geological and natural environment, as well as on the period in question (e.g., Keaveney, Reimer 2012.1314; Philippsen 2015.160-
162). A possible range of error in Karelia is illustrated by an Early Neolithic (Säräisniemi 1) vessel from the Kalmozero II site (Tab. 1): two dates from samples taken from the outer and inner surfaces of the same shard produced an offset of two to three centuries (Piezonka 2008.69, Abb. 2; also Hartz et al. 2012.1043)

\section{Evaluation}

The material available is biased: datings concentrate in certain areas and pottery types. Another major problem is the large share of conventional charcoal dates with poor link with actual archaeological materials. The standard errors of these conventional ${ }^{14} \mathrm{C}$-ages are generally large and vary from 20 to 150 (even 600) years, with the average between 80-90 years. This causes wide distributions in calibrated ages, at times providing accuracy of a millennium only. Laboratory-related issues are more difficult to assess, but as almost all conventional datings (over 98\% of the dates listed in Kochkurkina 1991 and Kosmenko 2003) originate from the same laboratory, i.e. Radiocarbon Laboratory of the Institute of Geology at the University of Tartu (see Liiva et al. 1975), they should be consistent. Nevertheless, the general quality of these datings can be expected to be fairly low by default, although no systematic evaluation of their reliability has been done (see $e . g$., Kuzmin, Tankerslay 1996; Pettitt et al. 2003; Seitsonen et al. 2012). Similar uncertainties apply to crust dates obtained through the conventional method re-dating of some shards with AMS showed that the unduly small samples used in the original dates made them unreliable and resulted in too young ages (Nordqvist, German 2017).

AMS-dated samples from clear archaeological contexts and with generally smaller standard errors (30-70 years BP, average 40 years BP) are also not free of problems. The potential reservoir effect is an important topic and no modern or ancient materials are currently available that could be used to reliably verify the offset in different reservoirs in the territory of Karelia. As AMS dates cluster quite nicely in many cases, it may be proposed that they still point towards the most likely use periods of different pottery types, whereas conventional dates have the tendency to disperse over a much wider period. Nevertheless, the current low number of AMS dates alone cannot be expected to provide precise dating for every cultural type and period.

With all this in mind, it can be stated that the chronology presented below operates within a margin 
of error of 100-200 years, and in some cases the offset may be even greater. Even if the initial and terminal dates of some pottery types must be considered tentative, the general tendencies are correct and the proposed timeframes are also generally accord with chronologies obtained in neighbouring areas.

\section{Radiocarbon chronology of the Karelian Repub- lic}

\section{Sperrings and Säräisniemi 1 Wares}

The oldest pottery in the Karelian Republic is Sperrings Ware, known also in Finland (where it is called older Early Comb Ware, style I:1, also Sperrings 1) (e.g., German 2011; Pesonen, Leskinen 2011). The earliest dates - charcoal from Uya III $(6770 \pm 80$ BP, TA-2352) and a burnt bone from Sulgu II (6670 35 BP, KIA-35900) - may be related to Mesolithic occupation at the sites and therefore reasonably questioned (Kosmenko 2003.32; German 2011.273274; Piezonka 2015.54). The charcoal date from Pegrema IX (6510 $\pm 150 \mathrm{BP}, \mathrm{TA}-1161)$ is usually referred to as the oldest certain date for Sperrings (Vitenkova 1996.78; German 2002.265, Tab. 1; Kosmenko 2003.32; Vereshchagina 2003.149), but it suffers from a large standard error. The earliest AMS dating also derives from Uya III (6225 $\pm 40 \mathrm{BP}$, GrA-63566) (Fig. 2), and is compatible with datings from Finland and Karelian Isthmus, which place the beginning of Sperrings Ware there to around 5300-5200 cal BC (Pesonen et al. 2012.664, Tab. 2; Piezonka 2015. 198-199, Abb. 170; Nordquist, Mökkönen 2016a. 204).
All the remaining conventional dates for Sperrings Ware originate in mixed contexts containing also partly temporally overlapping Pit-Comb Ware (see below) and date between 5500-4400 cal BC (medians 5400-4600 cal BC). The majority of crust/tar dates group around 5200-4500 cal BC (medians $5200-4600 \mathrm{cal} \mathrm{BC})$. The youngest date $(5507 \pm 50$ BP, KIA-35901) derives from a vessel slightly differing from the remaining Sperrings material at Vozhmarikha 26 (see Mel'nikov, German 2013.109). It is somewhat younger than the dates obtained in the surrounding areas, placing the end of Sperrings Ware at around $4400 \mathrm{cal} \mathrm{BC} \mathrm{(Pesonen} \mathrm{et} \mathrm{al.} 2012$. 664, Tab. 2; Seitsonen et al. 2012.110; Piezonka 2015.199, Abb. 170).

Almost coeval with Sperrings is Säräisniemi 1 Ware, which is characteristic of the northern Karelian Republic, Finland and Norway (e.g., Torvinen 2000; German 2011; Skandfer 2011). At the moment only three AMS dates exist for this type in Karelia - two dates of one shard from Kalmozero II $(6340 \pm 70 \mathrm{BP}$; KIA-35899A and $6080 \pm 45$ BP; KIA-35899B; the former date may include the reservoir effect, see above) and one date from Besovy Sledki (5775 $\pm 40 \mathrm{BP}$; GrA63547) (Fig. 3). All context dates previously connected with Säräisniemi 1 Ware derive from Yerpin Pudas I. They date between $c$. 5600-4000 cal BC (medians 5500-4100 cal BC) and may also be connected with other components present at the site, especially Pit-Comb Ware.

Dates from Karelia do not differ significantly from the range given for Säräisniemi 1 Ware in other re-

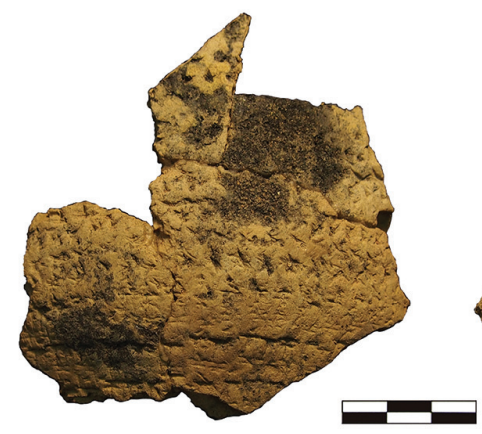

GrA-63566 Uya III (№ 2437/315, 666)

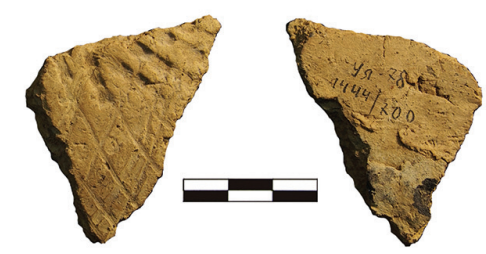

GrA-63546 Uya III (№ 1444/700)
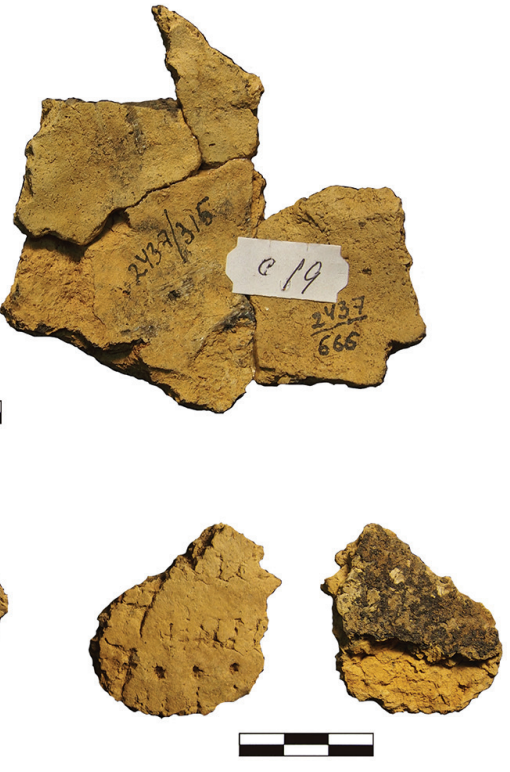

GrA-63587 Sheltozero V (№ 803/-)
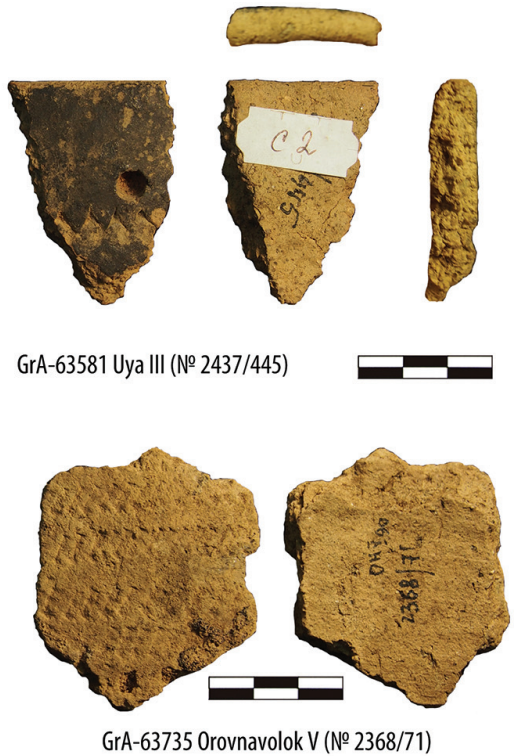

Fig. 2. Sperrings Ware (designed by T. Mökkönen). 
gions, i.e. 5300-4500 cal BC (Pesonen et al. 2012. 664, Tab. 2; Piezonka 2015.208-209, Abb. 174; Nordqvist, Mökkönen 2016a.204). ${ }^{1}$ In the light of current dates, it seems plausible that there is no significant temporal difference between Sperrings (Early Comb) and Säräisniemi 1 Wares in the north; in fact, in some areas, Säräisniemi 1 Ware precedes Sperrings Ware (also Pesonen et al. 2012.670). This further corroborates the recently-presented idea that Säräisniemi 1 Ware is not just a late northern variant of Sperrings Ware (see Pesonen 1991.84; Vitenkova 1996.81; Torvinen 2000.16; German 2006.234236; Pesonen, Leskinen 2011.300), but that these pottery types have different origins and development histories (Piezonka 2015.208-209). Furthermore, a few Finnish dates indicate that in some areas the use of Säräisniemi 1 Ware may have continued as late as the early $4^{\text {th }}$ millennium cal BC (Torvinen 1999.238; Carpelan 2004.29; Piezonka 2015.244; Nordqvist, Mökkönen 2016a.204).

Besides Sperrings and Säräisniemi 1 Wares, a few other pottery types dating to the $5^{\text {th }}$ millennium cal BC have been reported from Karelia: younger Early Comb Ware style I:2 (also Sperrings 2; see German 1998, who calls this pottery 'Early Comb Ware') and Kaunissaari Ware (also discussed under the umbrella term of Early Asbestos Ware; see Pesonen 1996. 24 ). Both types have their predominant distribution areas in Finland, where they are considered to be mostly younger than Sperrings Ware and dated between 4500 and $3800 \mathrm{cal} \mathrm{BC} \mathrm{(Pesonen} \mathrm{et} \mathrm{al.} 2012$.
664, Tab. 2; Oinonen et al. 2014.4, Tab. 1; Nordqvist, Mökkönen 2016a.204-205). No dates exist for these types in Karelia and, in general, they occur there very rarely.

\section{Pit-Comb Ware}

The emergence of Pit-Comb Ware in Karelia is traditionally connected with the Lyalovo culture, widespread in central and north-western Russia in the $5^{\text {th }}$ millennium cal BC, and probably especially with its later stage (Smirnov 1991; 1996; Gurina, Kraynov 1996; Vitenkova 2016.128; Smol'yaninov 2013. 238). At the moment, the chronology of Pit-Comb Ware is based mainly on context dates, as only four AMS dates exist from Besovy Sledki and Besovy Sledki II in the White Sea region (Fig. 3). Three of these date to the second half of the $5^{\text {th }}$ millennium cal BC, which has often been considered the main use period of this pottery type (Kosmenko 2003.32; Lobanova 2004.254,259), but the fourth one is younger (see below).

According to Nadežda V. Lobanova (2004.256; 2009. 58-59), who sees the first stage of Pit-Comb Ware as synchronous with Sperrings Ware, the oldest date that can be associated with Pit-Comb Ware comes from Chernaya Rechka I (6200 \pm 100 BP, TA-1634). In addition, there are also some other early context dates, but the connection between all these dates and Pit-Comb Ware contexts has been challenged (German 2002.264; Filatova 2012; see also Sidorov 1997.103-105). Accepting the early dates would also

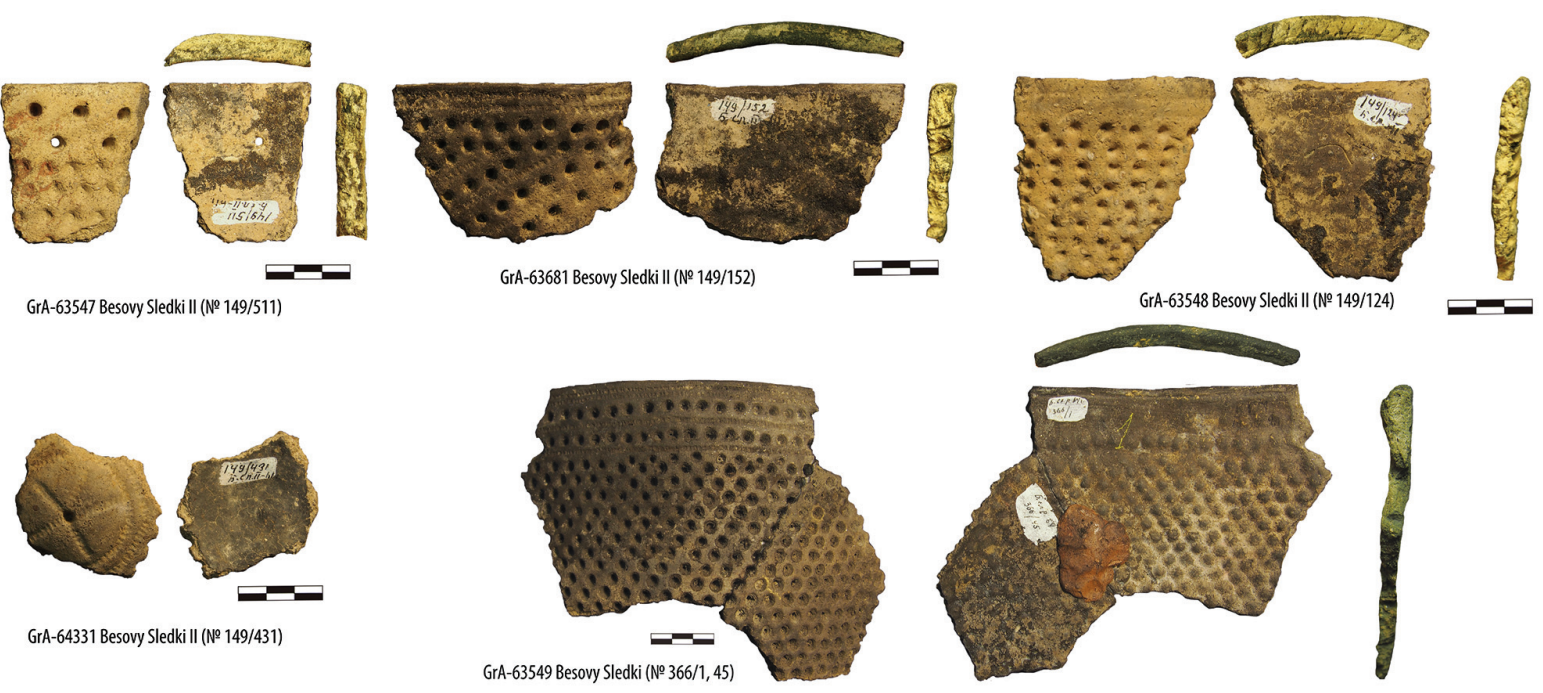

Fig. 3. Säräisniemi 1 Ware (upper left) and Pit-Comb Ware (designed by T. Mökkönen).

1 Also, older AMS dates have been presented for Säräisniemi 1 Ware from northern Norway (e.g., $6570 \pm 60$ BP, TUa-3018 and 6330 50 BP, TUa-3021; Skandfer 2011.356, Tab. 12.1), but these are affected by the marine reservoir effect (see Pesonen et al. 2012.667-668; Piezonka 2015.208). 
mean that Pit-Comb Ware in Karelia would be contemporaneous with the appearance of Lyalovo culture in the Upper-Volga region, currently dated to the very late $6^{\text {th }}$ millennium or to the turn of the $5^{\text {th }}$ millennium cal BC (Zaretskaya, Kostyleva 2011. 180-182; Hartz et al. 2012.1045).

Context dates connected with Pit-Comb Ware cover almost the whole of the $5^{\text {th }}$ millennium cal BC, but due to the above-mentioned uncertainties, the initial date must be placed only roughly in the first half of the $5^{\text {th }}$ millennium cal BC. Typologically, the final stage of Pit-Comb Ware has been seen to overlap with Comb-Pit and Rhomb-Pit Wares (Lobanova 2004.261; Khoroshun 2013.126-127), and a series of dates obtained from Vorob'i 4 showed that at least in some areas the use of Pit-Comb Ware continued during the first two or three centuries of the $4^{\text {th }}$ millennium cal BC.

In addition, there are dates which seem 'too young'. These include a crust date from Besovy Sledki II (4785 \pm 45 BP, GrA-64331). Typologically, this shard fits the characteristics of Pit-Comb Ware, but such a long continuation of use of this type seems very improbable (see also Nordqvist, Mökkönen $2017 a$ for discussion). A coeval context date of charcoal exists

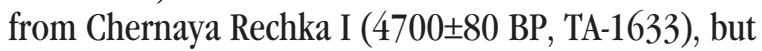
as there are two even much younger dates from the same site (with no corresponding archaeological material) it cannot be given much value. Finally, several crust dates produced by conventional methods from Vorob'i 4 are too young due to insufficient sample sizes (see Nordqvist, German 2017 for discussion).

\section{Comb-Pit and Rhomb-Pit Wares}

Comb-Pit Ware, corresponding to Typical Comb Ware of the eastern Baltic and Finland (Yanits 1959; Nordqvist, Mökkönen 2015), and Rhomb-Pit Ware, which finds analogies elsewhere in north-western and central Russia (Smirnov 1991; Smol'yaninov 2009; Vitenkova 2016), followed Pit-Comb Ware in Karelia. Traditionally, they were seen as subsequent types also among themselves, but the introduction of more accurate dating has shown them to be more or less contemporary (Zhul'nikov 2005.25; Khoroshun 2013.117; Vitenkova 2016.118). Currently, their chronology is based on many AMS and context dates, although the latter often originate from sites with mixed complexes of Comb-Pit and Rhomb-Pit Wares and cannot be attributed to only one of them. Based on some dates and stratigraphical observations (site Chernaya Guba III) it has been proposed that the appearance of Comb-Pit Ware would be slightly older, but the available data are too vague to draw such conclusions. In fact, it is not even known if the two assemblages at the same sites indicate the repeated use of these locations by two different groups or if both types were used by the same population (Vitenkova 2016.121).

Based on AMS dating, Comb-Pit Ware in Karelia dates to 4000-3600 cal BC (medians 4000-3700 cal BC) and Rhomb-Pit Ware 3900-3400 cal BC (medians 3800-3500 cal BC) (Figs. 4, 5). Most of the context dates fall between $4000-3100$ cal BC (medians 3900-3300 cal BC), within which the main use period of these types belongs. Such dating also fits the results from Finland, where an extensive dating programme has defined the use period of Typical Comb Ware from 3900 up to $3400 \mathrm{cal} \mathrm{BC} \mathrm{(Pesonen} 2004$. 90; Oinonen et al. 2014; authors' unpublished data). Chronology of Rhomb-Pit-related pottery is poorly known outside Karelia, and the only available direct dating (made of ceramic matrix) suggests that it existed between 3600-3100 cal BC (Skorobogatov et al. 2016.247).

However, there are context dates which date slightly older (Pegrema I, 5145 \pm 110 BP, TA-541 and Pegrema II, $5070 \pm 120 \mathrm{BP}$, TA-811) or even considerably younger (e.g., Pegrema I, 4200 \pm 50 BP, TA-493; Pegrema III, $4240 \pm 90 \mathrm{BP}, \mathrm{TA}-813){ }^{2}$ Even if they are at least partly related to other activities at these sites (e.g., Kosmenko 2003.25; Nordqvist, Mökkönen 2016b.232), it seems probable that, just as in some parts of Finland (Mökkönen 2008.123-124; also Seitsonen et al. 2012.111), Comb Ware tradition continued in Karelia in some form and in some areas until the early $3^{\text {rd }}$ millennium cal BC. Still, for example, the date from Lakshezero II $(3920 \pm 60 \mathrm{BP}$, TA1520), presented also as the final date for Comb-Pit Ware, probably belongs to the later asbestos potteryrelated use of this site (Vitenkova 2002.142).

In addition to uncertain context dates, one AMS dating from Chernaya Guba III $(6060 \pm 40$ BP, GrA-

2 The young dates from Pegrema I and Pegrema III are problematic because they have been presented quite differently in different publications. The date of $4240 \pm 90 \mathrm{BP}$ has also been given as $4200 \pm 90 \mathrm{BP}$, with index ID TA-813 or with no index ID; the date $4250 \pm 50 \mathrm{BP}$ (TA-493) has also been published as $4200 \pm 50 \mathrm{BP}$. Moreover, the date TA-813 has been said to originate from both of these sites (see Zhuravlev 1977; 1979; 1984; 1991; Zhuravlev, Liiva 1980; Kochkurkina 1991; Vitenkova 2002; Timofeev et al. 2004). 
63539) is problematic, as it is almost a millennium older than expected. The reservoir effect cannot be ruled out (the $\delta^{13} \mathrm{C}$ value is $-27.84 \%$ ), and there is always the possibility of typological misinterpretation, even if in this case the dated shard fully fits the characteristics of Comb-Pit Ware. If the date is even tentatively connected with the Pit-Comb Ware, recovered in small amounts at this site (Vitenkova 2002.29), it would also be by far the oldest direct date of Pit-Comb Ware in Karelia. Furthermore, two conventional dates of pottery crust from Vozhmarikha 21 may date to the end phase of Comb-Pit Ware use, but may also suffer from the same problems discussed in connection with the Pit-Comb Ware dates from Vorob'i 4.

Finally, a date measured on birch bark found in a

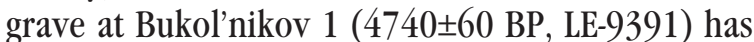
been connected with Comb-Pit Ware (Mel'nikov, German 2013.120), even if no Comb-Pit Ware was found at the site. The grave goods, e.g., amber jewellery and a bifacial flint point, may be seen to support this connection. However, the assemblage from the site includes mostly Pit-Comb Ware and some asbes-

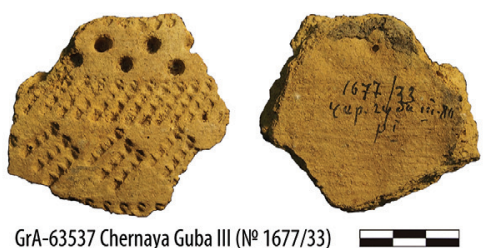

(19:8)
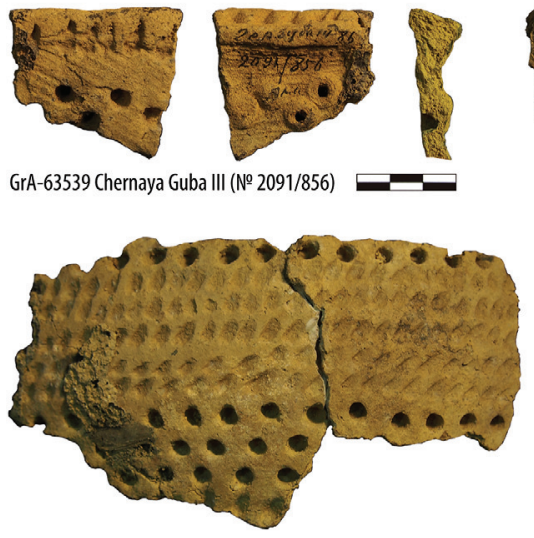

GrA-63540 Chernaya Guba III (№ 2226/593)

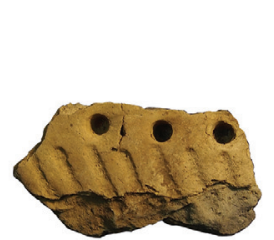

GrA-63588 Sheltozero V (№ 803/15)
GrA-63539 Chernaya Guba III (NN 2091/856)

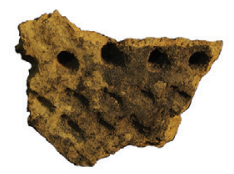

GrA-63538 Chernaya Guba III (№ 2091/338)
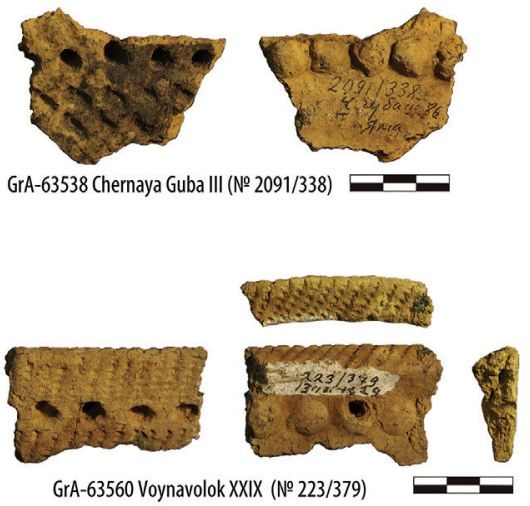

GrA-63560 Voynavolok XXIX (№223/379)
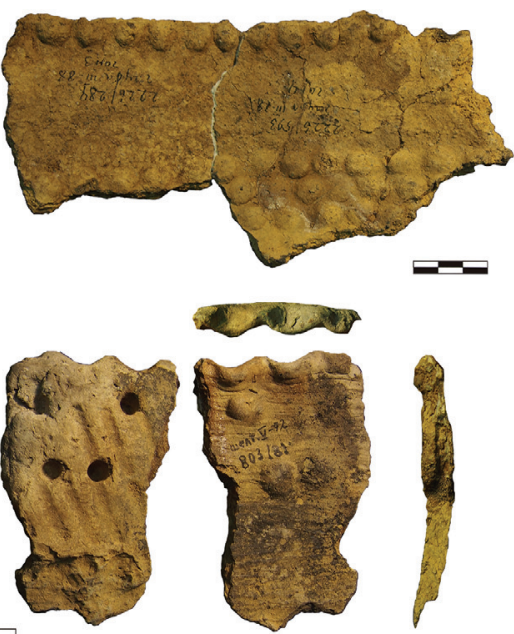

Fig. 4. Comb-Pit Ware (designed by T. Mökkönen). tos-tempered pottery of possibly Voynavolok type within the temporal limits provided by the date, the burial could also be connected with the latter phase.

\section{Zalavruga, Voynavolok, Orovnavolok and Pa- layguba Wares}

Previously, all asbestos- and organic-tempered pottery in Karelia was discussed under the one heading of Asbestos or Classic Ware (Gurina 1961.161; Kosmenko 1992.131). Such a view does not permit the tracing of cultural dynamics during the $4^{\text {th }}-2^{\text {nd }}$ millennia cal BC, and since then four types of pottery have been separated from the material: Zalavruga, Voynavolok, Orovnavolok and Palayguba Wares Zhul'nikov 1991; 1999; 2005). These types have arying distributions mainly in Karelia and find some parallels in the Finnish types of Kierikki and öljä. They have also contemporary analogues in east, and generally the emergence of asbestosorganic-tempered pottery in Karelia has been colosovo (Z) Volga-Oka region (Zhul'nikou 1999.6-7 and references cited). The starting point of Volosovo in the Upper Volga region is dated to around 3600 cal BC (Kostyleva, Utkin 2010.248-250).

Asbestos- and organic-tempered wares are relatively well dated by AMS and context dates (including numerous dates from burnt dwelling constructions), although the dates are unevenly distributed among the pottery types. There are also notably many 'non- fitting' dates connected to sites with these pottery types or their use periods (see Table 2).

The oldest date connected with asbestos- and organic-tempered pottery in Karelia is a tar date related to Voynavolok Ware (Pervomayskaya I, $4710 \pm 35$ BP, GrA-63682) (Fig. 6). Generally, AMS dates for this type fall between 3600-2900 cal BC (medians 3500-3000 cal BC) and cluster into two groups between 3600-3400 cal BC and 34002900 cal BC. The first cluster corresponds neatly with older ideas of a short use period of 

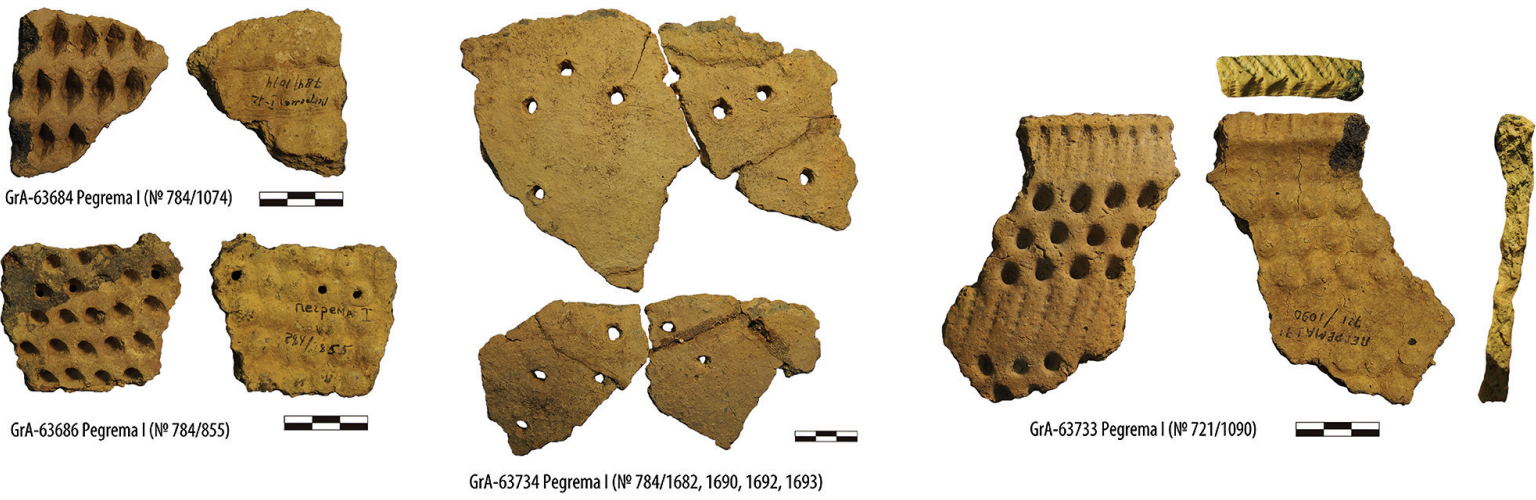

Fig. 5. Rhomb-Pit Ware (designed by T. Mökkönen).

this pottery type, just a few centuries in the mid-4th millennium cal BC (Zhul'nikov 1999.47, 76-78; also Zhul'nikov, Tarasov 2014.262). The second cluster is contemporary with the few available context dates from burnt dwelling constructions (3300-2600 cal BC, medians 3100-2900 cal BC).

In other words, the beginning of Voynavolok Ware may be dated to the mid-4th millennium cal BC. Such dating is also supported by Finnish material, where Kierikki Ware is dated between 3600 and $2900 \mathrm{cal} \mathrm{BC}$ (Pesonen 2004.90, 92; Nordqvist, Mökkönen 2017b; Mökkönen, Nordqvist in prep.). Like Voynavolok Ware, Kierikki Ware is seen as a descendant of the Comb Ware tradition, and some of the heterogeneous material classified as Kierikki bears considerable resemblance to Voynavolok Ware (Nordqvist, Mökkönen 2017b; Mökkönen, Nordqvist in prep.). Furthermore, some pottery labelled (erroneously) as Kierikki is actually pure Voynavolok type (pottery from Vuopaja; Zhulnikov et al. 2012.127; this is the oldest AMS-dated Voynavolok shard, $4805 \pm 85$ BP, Ua-4364; Carpelan 2004).

The end date of Voynavolok Ware should be placed in the first centuries of the $3^{\text {rd }}$ millennium cal BC, at the latest. However, the youngest dates (Voynavolok XXVII, 4280 \pm 80 BP, GrA-63562 and Fofanovo
XIII, $4470 \pm 60 \mathrm{BP}$, GrA-62484) derive from shards that also allow typological attribution to Orovnavolok Ware or represent a so-called 'transitional type' between these two (see Zhul'nikov, Tarasov 2014. 261; Tarasov 2015.250; also Nordqvist, Mökkönen $2017 a$ for discussion). Respectively, the same reason, in addition to a possible freshwater reservoir effect, explains the overlap of Voynavolok type and the oldest dates connected with Orovnavolok Ware (Orovnavolok XVI, $4770 \pm 40$ BP, Beta-117966; Fofa-

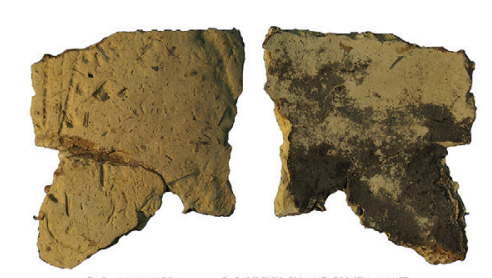

GrA-63565 Voynavolok XXVII (№ 2PGU/"1458")
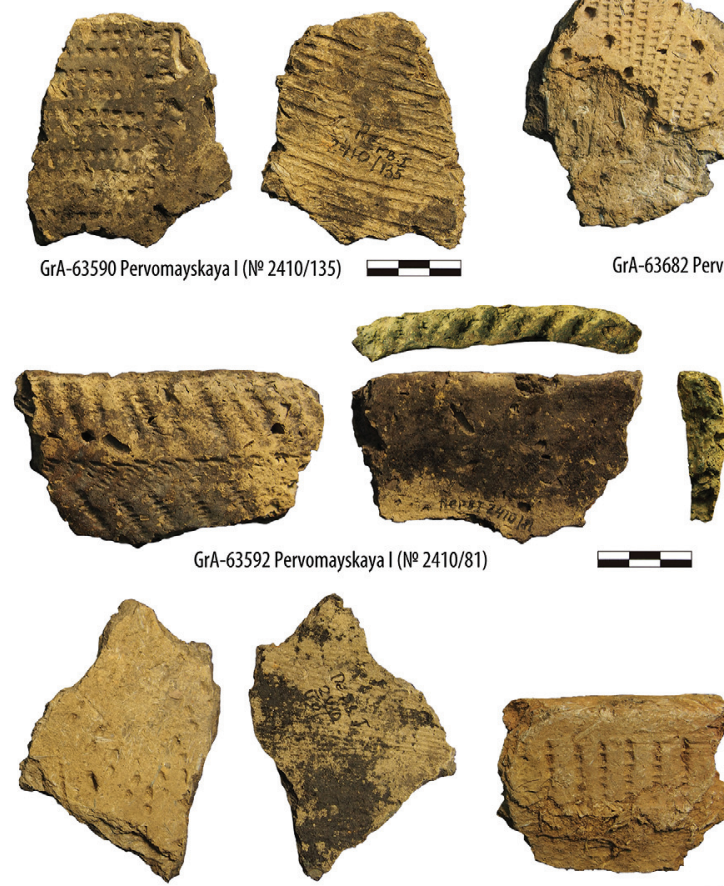

GrA-63683 Pervomayskaya I (№ 2410/421)
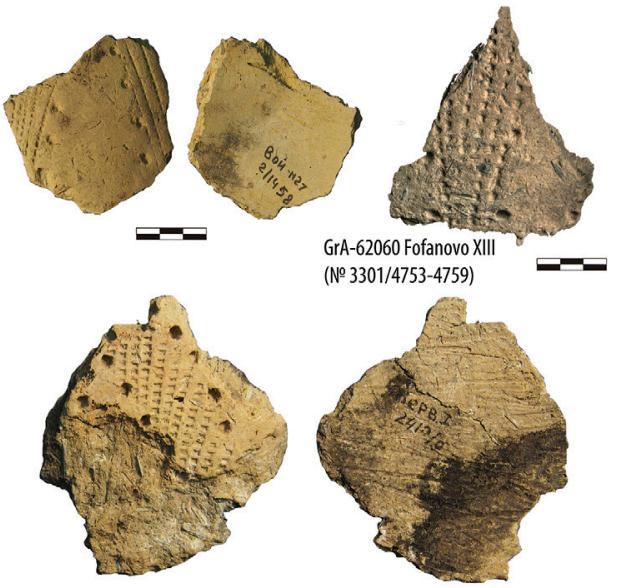

GrA-63682 Pervomayskaya I (№ 2410/9)

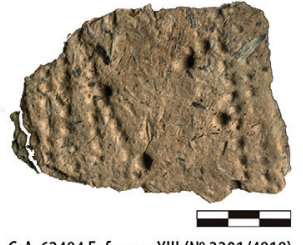

GrA-62484 Fofanovo XIII (№ 3301/4818)
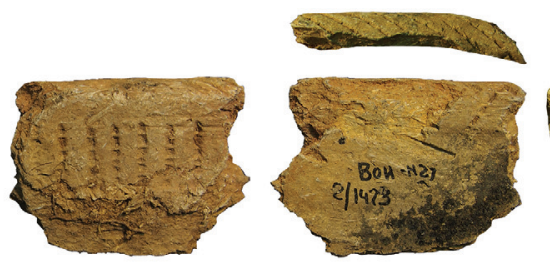

GrA-63562 Voynavolok XXVII (№ 2PGU/1473)

Fig. 6. Voynavolok Ware (designed by T. Mökkönen). 

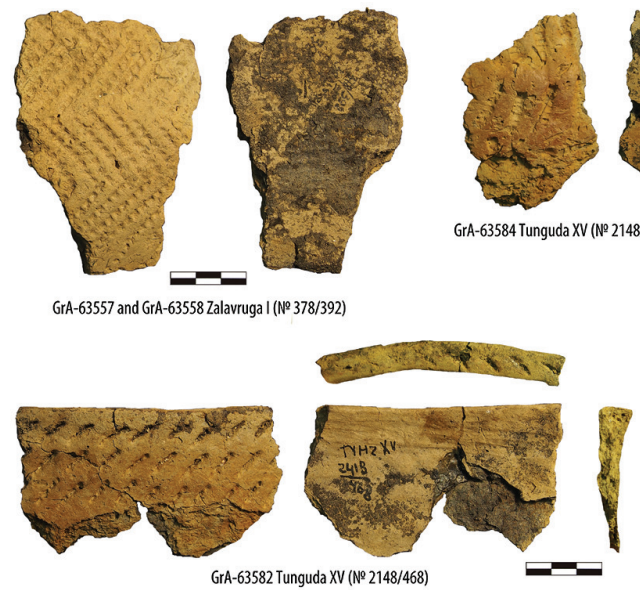

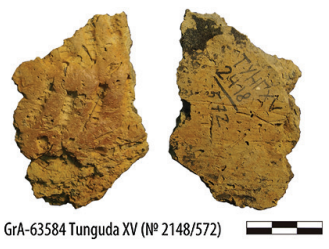

GrA-63584 Tunguda XV (№ 2148/572)
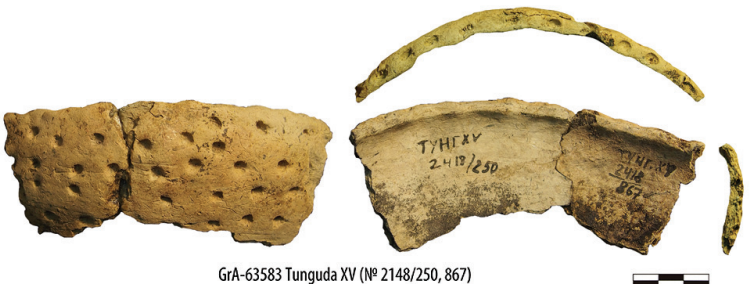

GrA-63583 Tunguda XV (№ 2148/250, 867)
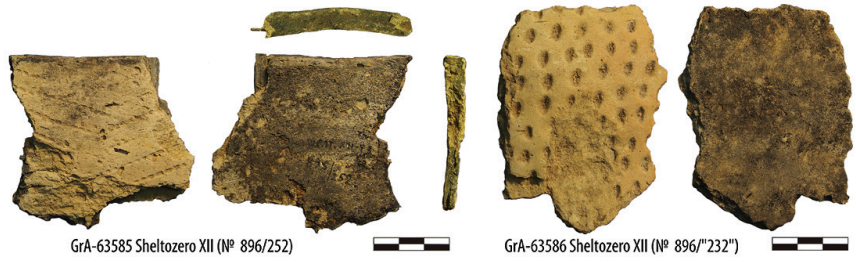

Fig. 7. Orovnavolok Ware and Palayguba Ware (bottom row) (designed by T. Mökkönen).

novo XIII, 4585 \pm 35 BP, GrA-62059; Tunguda XV, $4570 \pm 35$ BP, GrA-63583) (Fig. 7). This typological overlap is well-evidenced by material and dates from Fofanovo XIII, where, however, Voynavolok pottery has generally been recovered in lower stratigraphic layers than the Orovnavolok type (Zhul'nikov, Tarasov 2014; Tarasov 2015).

The remaining AMS dates of Orovnavolok Ware fall between 3300-2700 cal BC (medians 3200-2900 cal BC) and are roughly congruent with the majority of context dates from dwelling constructions, 3100$2600 \mathrm{cal} \mathrm{BC}$ (medians $2800 \mathrm{cal} \mathrm{BC}$ ). Still, there are a few dates some centuries younger, although it is highly implausible that at least the youngest date (Voynavolok XXIV, 3560 \pm 80 BP, TA-819) would anymore represent the use period of Orovnavolok Ware.

In sum, the start of this type should be a bit later than Voynavolok Ware and probably dates to around $3400 \mathrm{cal} \mathrm{BC}$, although the nature of the 'transitional type' remains ambivalent. The end date can probably be placed in the first half of the $3^{\text {rd }}$ millen- nium cal BC, and no later than $2500 \mathrm{cal} \mathrm{BC}$. Thus, in addition to Kierikki and Voynavolok Wares, it belongs to the same chronological horizon as Pöljä Ware of Finland, with which it also shares some typological and stylistic similarities (pure Orovnavolok Ware has been recognised in Finland on some occasions; Nordqvist, Mökkönen 2017b; Mökkönen, Nordqvist in prep.; see also Zhul'nikov 2005.29). Pöljä Ware is dated by AMS dates to $3500-2500$ cal $\mathrm{BC}$, but including context datings, its end has been extended to $c .1900$ cal BC (Pesonen 2004.90, 92; authors' unpublished data).

Zalavruga Ware of the White Sea area has been considered a northern parallel to Voynavolok pottery (Zhul'nikov 2005.27). Its dating is based on a few crust/tar dates only, as all context dates derive from mixed sites and have no definite connection with this pottery (Fig. 8). AMS dates fall between 3500 and $2900 \mathrm{cal} \mathrm{BC}$ (medians 3400-2900 cal BC), whereas conventional dates date to $3700-1800 \mathrm{cal} \mathrm{BC}$. In other words, the main use period of Zalavruga Ware is the second half of the $4^{\text {th }}$ millennium cal BC.
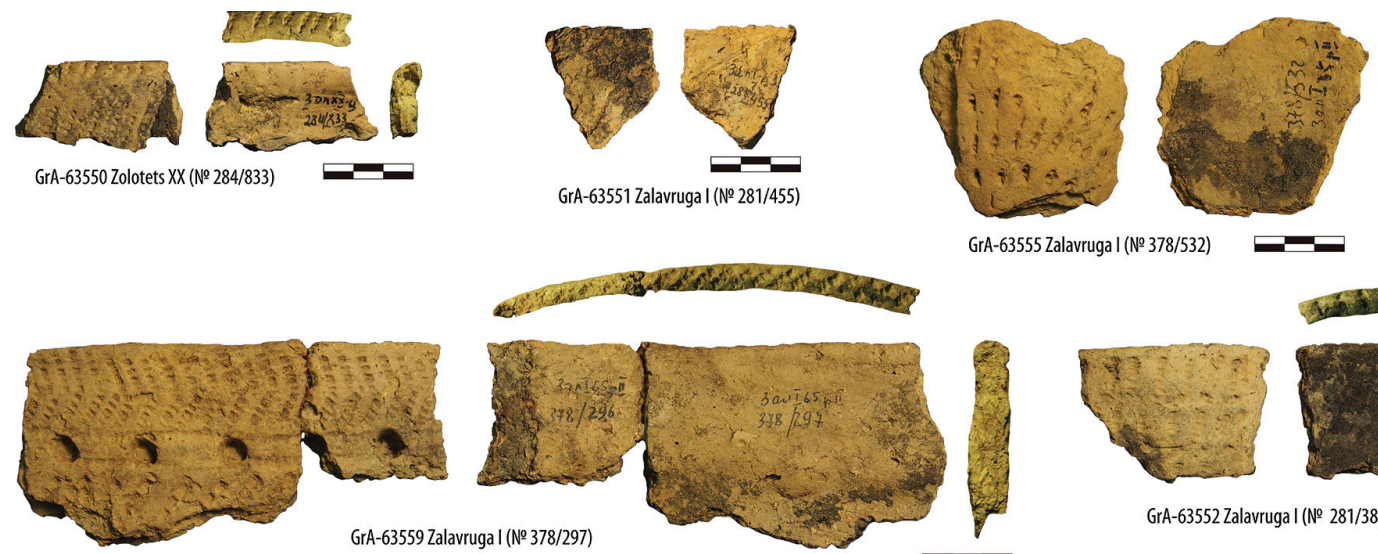

GrA-63555 Zalavruga I (№ 378/532)
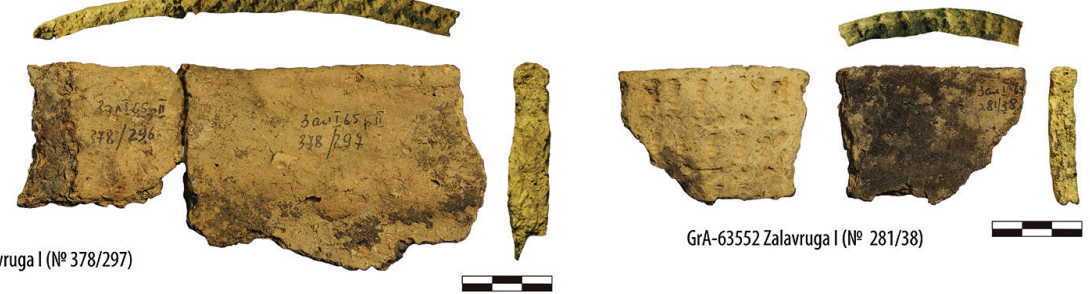

Fig. 8. Zalavruga Ware (designed by T. Mökkönen). 
It is largely contemporary with Voynavolok Ware, but also overlaps with Orovnavolok Ware, as also evidenced by coeval datings from the Zalavruga I site. Zalavruga Ware shares some features with Kierikki Ware and the organic-tempered Comb Ware of northern Finland, but their relationships remain unresolved (Zhul'nikov 2007.123; Nordqvist, Mökkönen 2017b; Mökkönen, Nordqvist in prep.).

The youngest type of Neolithic/Eneolithic asbestosand organic-tempered potteries is Palayguba Ware. Currently, only two AMS datings exist for it (Sheltozero XII, $3815 \pm 35$ BP, GrA-63585 and $3725 \pm 35$ BP, GrA-63586) (Fig. 7). In this case, context dates from dwellings suggest a somewhat earlier dating. The oldest derives from Kudomguba VII $(4010 \pm 80 \mathrm{BP}$, TA-1893), but the most dates from clear Palayguba contexts date younger than $2600 \mathrm{cal} \mathrm{BC}$ and up to the first centuries of the $2^{\text {nd }}$ millennium cal $\mathrm{BC}$ (2900-1700 cal BC, medians 2500-1900 cal BC). Thus, it seems to overlap little with Orovnavolok Ware, to which it has been also genetically connected, as well as with Corded Ware/Fat'yanovo cultures, which have been seen to influence it too (Zhul'nikov 1999). Temporally, Palayguba Ware is largely coeval also with Pöljä Ware, and the end date proposed for the latter, 1900/1800 cal BC, may well apply to most Palayguba pottery.

However, there are even younger dates connected with Palayguba Ware (the youngest date is from Palayguba II, $3150 \pm 100 \mathrm{BP}$, TA-1007), although some of these may already belong to the context of subsequent Textile Ware present at some sites. No genetic relationship has been proposed between these two pottery types, and their overlap remains an open question. In Karelia, the oldest context dates connected with Textile Ware date to the turn of the $3^{\text {rd }}$ and $2^{\text {nd }}$ millennia cal $\mathrm{BC}$ or the first half of the $2^{\text {nd }}$ millennium cal BC (Kelka III, 3520 \pm 80 BP, TA-2269 and $3100 \pm 70$ BP, TA-2268; Zhul'nikov 1999.77). They are fairly consistent with the earliest AMS dates of
Textile Ware from Finland, starting from the early $2^{\text {nd }}$ millennium cal BC onwards (Lavento 2001.102, Fig. 6.11, 106). AMS dates for Textile Ware in Karelia fall between $c$. 1500-1300 cal BC (Kosmenko 2003).

\section{Final remarks}

The data presented in this paper are still limited in temporal and spatial coverage, and do not allow the study of regional and temporal differences in the distribution of various phenomena in detail. In an area as large as the Karelian Republic, it is not reasonable to assume that development (e.g., appearance or disappearance of a pottery type) would have been simultaneous or similar everywhere. Instead, there might have been large differences (for example, some pottery types may have existed for longer periods in certain areas), which can cause inconsistency in the data and 'deviatory' initial and terminal dates.

Similarly, the data are too thin to provide reliable evidence of the temporal differences of some pottery types proposed on typological grounds, or to be used in statistical analyses defining certain event sequences. Also, potential sources of error - like the old wood and the (freshwater) reservoir effect - must be studied in the future, as this might also clarify the reason behind the differences between residue-based AMS and conventional charcoal dates.

Despite the numerous problems and unanswered questions, the currently available radiocarbon dates enable the study of chronological sequences in $\mathrm{Ka}$ relia in much greater detail than was possible even two or three years ago. Nowadays, it is also possible to correlate the Karelian chronology more or less precisely with the general north-east European chronological framework. All this creates a better foundation for understanding the cultural dynamics between the later $6^{\text {th }}$ and the early $2^{\text {nd }}$ millennia cal BC of north-western Russia.

\section{ACKNOWLEDGEMENTS}

This paper was partly produced with the support of a state contract within the current research project of the Department of Archaeology of the Institute of Linguistics, Literature and History of the Karelian Research Centre of Russian Academy of Sciences (state registration number \#0225-2014-0014) (AT and TKh). The majority of Karelian AMS dates, as well as part of writing this paper (KN and TM), were funded by the project 'The use of materials and the Neolithisation of North-Eastern Europe (c. 6000-2000 BC)' (Academy of Finland \& University of Oulu, 2013-17, project \#269066). One previously unpublished date of burnt bone (Fofanovo XIII site) was obtained through financial support from the Russian Scientific Fund (grant \#14-17-00766). The authors also wish to thank K. E. German (Petrozavodsk) for the possibility to include dates from the Vorob' $i$ and Vozhmarikha sites in this article, as well as N. V. Lobanova (Petrozavodsk) for the use of two previously partially published dates from Orovnavolok XVI. 


\section{References}

Bronk Ramsey C. 2009. Bayesian analysis of radiocarbon dates. Radiocarbon 51(1): 337-360. doi: 10.1017/S0033 822200033865

Carpelan C. 2004. Environment, archaeology and radiocarbon dates: Notes from the Inari region, northern Finnish Lapland. In M. Lavento (ed.), Early in the North: Volume 5: The Land. Iskos 13. The Finnish Antiquarian Society. The Archaeological Society of Finland. Helsinki: 17-45.

Devyatova E. I. 1976. Geologiya i palinologiya golotsena $i$ khronologiya pamyatnikov pervobytnoy epokhi v yugozapadnom Belomor'e. Nauka. Leningrad. (in Russian)

1986. Prirodnaya sreda i ee izmeneniya $v$ golotsene (poberezh'e severa $i$ tsentra Onezhskogo ozera). Karel'skiy filial Akademii Nauk SSSR. Petrozavodsk. (in Russian)

Filatova V. F. 2012. Mezoliticheskie pamyatniki Karelii: Katalog. Karel'iskiy nauchniy tsentr Rossiyskaya Akademiya Nauk. Petrozavodsk. (in Russian)

Fischer A., Heinemeier J. 2003. Freshwater reservoir effect in ${ }^{14} \mathrm{C}$ dates of food residue on pottery. Radiocarbon 45(3): 449-466. doi: 10.1017/S003382220003280X

German K. E. 1998. Rannyaya grebechataya keramika v basseyne Onezhskogo ozera. Tverskoy arkheologicheskiy sbornik 3: 266-272. (in Russian)

2002. Khronologiya i periodizatsiya kul'tury sperrings v Karelii. Tverskoy arkheologicheskiy sbornik 5(1): 264273. (in Russian)

2006. Pamyatniki s keramikoy Syaryaisniemi I v severnoy Karelii. In A. Ya. Martynov (ed.), Pervobytnaya $i$ srednevekovaya istoriya $i$ kul'tura Evropeyskogo Severa: Problemy izucheniya i nauchnoy rekonstruktsii. Solti. Solovki: 22-24. (in Russian)

2011. Early hunter-gatherer ceramics in Karelia. In P. Jordan, M. Zvelebil (eds.), Ceramics before Farming: the Dispersal of Pottery among Prehistoric Eurasian Hunter-Gatherers. Left Coast Press. Walnut Creek: 255-280.

2012. Kul'tura sperrings na territorii Karelii. In S. V. Oshibkina (ed.), Pervobytnye drevnosti Evrazii. Institut Arkheologii Rossiyskaya Akademiya Nauk. Moskva: 571-591. (in Russian)

2016. Novye radiouglerodnye opredeleniya po nagaru $s$ neo-eneoliticheskoy keramiki Karelii. Presentation held at the Tver archaeological seminar, 25.3.2016. (in Russian)
Gurina N. N. 1961. Drevnyaya istoriya Severo-Zapada Evropeyskoy chasti SSSR. Materialy i issledovaniya po arkheologii SSSR 87. Izdatel'stvo Akademii Nauk SSSR. Moskva-Leningrad. (in Russian)

Gurina N. N., Kraynov D. A. 1996. L'yalovskaya kul'tura In S. V. Oshibkina (ed.), Neolit Severnoy Evraziya. Arkheologiya. Nauka. Moskva: 173-182. (in Russian)

Hartz S. Kostyleva E., Piezonka H., Terberger T., Tsydenova N. and Zhilin M. G. 2012. Hunter-gatherer pottery and charred residue dating: New results on early ceramics in the north Eurasian forest zone. Radiocarbon 54(3-4): 1033-1048. doi: 10.2458/azu_js_rc.v54i3-4.16162

Herva V.-P., Nordqvist K., Lahelma A. and Ikäheimo J. 2014. Cultivation of perception and the emergence of the Neolithic world. Norwegian Archaeological Review 47 (2): 141-160. doi: 10.1080/00293652.2014.950600

Herva V.-P., Mökkönen T. and Nordqvist K. 2017. A Northern Neolithic? Clay work, cultivation and cultural transformations in the boreal zone of north-eastern Europe, $c$. 5300-3000 BC. Oxford Journal of Archaeology 36(1): 25-41. doi: 10.1111/ojoa.12103

Ikäheimo J., Nordqvist K. 2017. Lost in narration: Rediscovering the Suomussalmi copper adze. Norwegian Archaeological Review 50(1): 1-22. doi: 10.1080/0029365 2.2017.1307268

Ikäheimo J., Pääkkönen M. 2009. Kierikin kupariveitsi: Uusimpia tutkimustuloksia. In J. Ikäheimo, S. Lipponen (eds.), Ei kiveäkään kääntämättä. Pentti Koivusen juhlakirjatoimikunta. Oulu: 161-173.

Keaveney E. M., Reimer P. J. 2012. Understanding the variability in freshwater radiocarbon reservoir offsets: a Cautionary tale. Journal of Archaeological Science 39 (5): 1306-1316. doi: 10.1016/j.jas.2011.12.025

Khoroshun T. A. 2013. Pamyatniki s yamochno-grebenchatoy $i$ rombo-yamochnoy keramikoy na zapadnom poberezh'e Onezhskogo ozera (konets V - nachalo III tys. do n.e.). Unpublished $\mathrm{PhD}$ thesis. Karel'iskiy nauchniy tsentr Rossiyskaya Akademiya Nauk. Petrozavodsk. (in Russian)

2015. K voprosu o khronologii i periodizatsii pamyatnikov s yamochno-grebenchatoy, grebenchato-yamochnoy i romboyamochnoy keramikoy zapadnogo poberezh'ya Onezhskogo ozera. Tverskoy arkheologicheskiy sbornik 10(1): 34-41. (in Russian)

Kochkurkina S. I. (ed.) 1991. Khronologiya i periodizatsiya arkheologicheskikh pamyatnikov Karelii. Karel'i- 
skiy nauchniy tsentr Rossiyskaya Akademiya Nauk. Petrozavodsk. (in Russian)

Kosmenko M. G. 1992. Mnogosloynye poseleniya yuzhnoy Karelii. Karel'iskiy nauchniy tsentr Rossiyskaya Akademiya Nauk. Petrozavodsk. (in Russian)

2003. Problemy datirovaniya i khronologiya pamyatnikov Karelii (kamenniy, bronzoviy, zhelezniy veka). Rossiyskaya Arkheologiya 2003(4): 25-35. (in Russian)

2004. The chronology of the Stone-Iron Ages of the Karelian Republic. In P. Uino (ed.), Fenno-ugri et Slavi 2002: Dating and Chronology. Museoviraston arkeologian osaston julkaisuja 10. National Board of Antiquities. Helsinki: 46-55.

Kosmenko M. G., Kochkurkina S. I. (eds.) 1996. Arkheologiya Karelii. Karel'iskiy nauchniy tsentr Rossiyskaya Akademiya Nauk. Petrozavodsk. (in Russian)

Kostyleva E. L., Utkin A. V. 2010. Neo-eneoliticheskie mogilniki verkhnego Povolzh'ya i Volgo-Okskogo mezhdurech'ya: Planigraphichskie i khronologicheskie struktu$r y$. TAUS. Moskva. (in Russian)

Kulkova M., Mazurkevich A., Dolbunova E., Regert M., Mazuy A., Nesterov E. and Sinai M. 2015. Late Neolithic subsistence strategy and reservoir effects in ${ }^{14} \mathrm{C}$ dating of artefacts at the pile-dwelling site Serteya II (NW Russia). Radiocarbon 57(4): 611-623. doi: 10.2458/azu_rc.57.18427

Kuzmin Y. V., Tankerslay K. B. 1996. The colonization of eastern Siberia: an Evaluation of the Paleolithic Age radiocarbon dates. Journal of Archaeological Science 23(4): 577-585. doi: 10.1006/jasc.1996.0054

Lavento M. 2001. Textile Ceramics in Finland and on the Karelian Isthmus: Nine Variations and a Fugue on a Theme of C. F. Meinander. Suomen Muinaismuistoyhdistyksen Aikakauskirja 109. The Finnish Antiquarian Society. Helsinki.

Liiva A. A., Il'ves E. O. and Punning Ya.-M. K. 1975. Radiouglerodnye issledovaniya v laboratorii geobiokhimii. Akademiya Nauk ESSR. Tartu. (in Russian)

Lobanova N. V. 1988. Poseleniya s yamochno-grebenchatoy keramikoy. In S. I. Kochkurkina (ed.), Poseleniya drevney Karelii (ot mezolita do srednevekov'ya). Karel'skiy filial Akademii Nauk SSSR. Petrozavodsk: 50-66. (in Russian)

2004. Khronologiya i periodizatsiya pamyatnikov s yamochno-grebenchatoy keramikoy na territorii Karelii. In V. I. Timofeev, G. I. Zaytseva (eds.), Problemy khro- nologii i etnokulturnykh vzaymodeystviy $v$ neolite $\mathrm{Ev}$ razii. Institut istorii material'noy kul'tury Rossiyskaya Akademiya Nauk. Sankt-Peterburg: 253-264. (in Russian)

2009. Adaptatsionnye protsessy v kul'ture naseleniya Karelii epokhi neolita. In M. G. Kosmenko (ed.), Adaptatsiya kul'tury naseleniya Karelii $k$ osobennostyam mestnoy prirodnoy sredy periodov mesolita - srednevekov'ya. Karel'iskiy nauchniy tsentr Rossiyskaya Akademiya Nauk. Petrozavodsk: 44-68. (in Russian)

Mel'nikov I. V., German K. E. 2013. Drevnie poseleniya yuzhnogo Zaonezhya (mezolit - eneolit). Gosudarstvenniy istoriko-arkhitekturniy i etnograficheskiy muzey-zapovednik 'Kizhi'. Petrozavodsk. (in Russian)

Mökkönen T. 2008. A review of Neolithic multi-room housepits as seen from the Meskäärtty site in Virolahti parish, extreme south-eastern Finland. Estonian Journal of Archaeology 12(2): 114-151. doi: 10.3176/arch.2008.2.02

Mökkönen T., Nordqvist K. in prep. The concept of Kierikki Ware and the heterogeneous potteries of the mid- $4^{\text {th }}$ and early $3^{\text {rd }}$ millennia cal BC in north-east Europe. Paper submitted.

Nordqvist K. 2013. Periodizatsiya neolita-bronzogo veka v Severo-Vostochnoy Evrope/Of the periodization of Eneolithic-Bronze Age in north-east Europe. In V. S. Bochkarev, A. I. Murashkin (eds.), Problemy periodizatsii i khronologii $v$ arkheologii epokhi rannego metalla Vostochnoy Evropy. Sankt-Peterburg gosudarstvenniy universitet. Sankt-Peterburg: 188-199. (in Russian/English)

Nordqvist K., German K. 2017. New remarks on the chronology of Pit-Comb Ware in Karelia (north-west Russia). Fennoscandia Archaeologica XXXIV: in press.

Nordqvist K., Herva V.-P. 2013. Copper use, cultural change and Neolithization in north-eastern Europe (c. 5500-1800 BC). European Journal of Archaeology 16(3): 401-432. doi: 10.1179/1461957113Y.0000000036

Nordqvist K., Mökkönen T. 2015. Äyräpää's Typical Comb Ware: an Umbrella term for the early $4^{\text {th }}$ millennium BC pottery in northeastern Europe? Fennoscandia Archaeologica XXXII: 151-159. http://www.sarks.fi/fa/faxxxii. html

2016a. New radiocarbon dates for early pottery in north-eastern Europe. In O. V. Lozovskaya, A. N. Mazurkevich and E. V. Dolbunova (eds.), Traditsii i innovatsiii v izuchenii drevneyshey keramiki. Institut istorii material'noy kul'tury, Gosudarstvenniy Ermitazh, Samarskii gosudarstvenniy sotsial'no-pedagogicheskiy universitet. Sankt-Peterburg: 204-214. 
2016b. A Stone Age strainer from the northern boreal zone: a Find from Pegrema I (Karelian Republic). Fennoscandia Archaeologica XXXIII: 231-236. http:// www.sarks.fi/fa/faxxxiii.html

2017a. Novye dannye po arkheologicheskoy khronologii Severo-Zapada Rossii: AMS datirovki neolita-eneolita Karelii. Tverskoy arkheologicheskiy sbornik 11: in press. (in Russian)

2017b. Keramika tipa Kierikki: datirovka i paralleli v severo-vostochnoy Evrope. Tverskoy arkheologicheskiy sbornik 11: in press. (in Russian)

2017c. Periodization of the Neolithic and radiocarbon chronology of the Early Neolithic and the beginning of Middle Neolithic in Finland. Documenta Praehistorica 44 :

Oinonen M., Pesonen P., Alenius T., Heyd V., HolmqvistSaukkonen E., Kivimäki S., Nygrén T., Sundell T. and Onkamo P. 2014. Event reconstruction through Bayesian chronology: Massive mid-Holocene lake-burst triggered large-scale ecological and cultural change. The Holocene 24(11): 1419-1427. doi: 10.1177/0959683614544049

Olsen J., Heinemeier J., Lübke H., Lüth F. and Terberger T. 2010. Dietary habits and freshwater reservoir effects in bones from a Neolithic NE German cemetery. Radiocarbon 52(2-3): 635-644. doi: 10.1017/S0033822200045 665

Pankrushev G. A. 1988. Poseleniya s asbestovoy keramikoy. In S. I. Kochkurkina (ed.), Poseleniya drevney Karelii (ot mezolita do srednevekov'ya). Karel'skiy filial Akademii Nauk SSSR. Petrozavodsk: 79-97. (in Russian)

Pesonen P. E. 1988. Poseleniya kul'tury sperrings. In S. I. Kochkurkina (ed.), Poseleniya drevney Karelii (ot mezolita do srednevekov'ya). Karel'skiy filial Akademii Nauk SSSR. Petrozavodsk: 40-49. (in Russian)

1991. Khronologiya i periodizatsiya kul'tury sperrings. In S. I. Kochkurkina (ed.), Khronologiya i periodizatsiya arkheologicheskikh pamyatnikov Karelii. Karel'iskiy nauchniy tsentr Rossiyskaya Akademiya Nauk. Petrozavodsk: 65-85. (in Russian)

Pesonen P. 1996. Early Asbestos Ware. In T. Kirkinen (ed.), Pithouses and Potmakers: Reports of the Ancient Lake Saimaa Project. Helsinki Papers in Archaeology 9. University of Helsinki. Helsinki: 9-39.

2004. Neolithic pots and ceramic chronology: AMS-datings of Middle and Late Neolithic ceramics in Finland. In P. Uino (ed.), Fenno-ugri et Slavi 2002: Dating and Chronology. Museoviraston arkeologian osaston julkaisuja 10. National Board of Antiquities. Helsinki: 87-97.
Pesonen P., Leskinen S. 2011. Pottery of the Stone Age hunter-gatherers in Finland. In P. Jordan, M. Zvelebil (eds.), Ceramics before Farming: the Dispersal of Pottery among Prehistoric Eurasian Hunter-Gatherers. Left Coast Press. Walnut Creek: 299-318.

Pesonen P., Oinonen M., Carpelan C. and Onkamo P. 2012. Early Subneolithic ceramic sequences in eastern Fennoscandia: a Bayesian approach. Radiocarbon 54(3-4): 661676. doi: 10.2458/azu_js_rc.v54i3-4.16138

Pettitt P. B., Davies W., Gamble C. S. and Richards M. B. 2003. Palaeolithic radiocarbon chronology: Quantifying our confidence beyond two half-lives. Journal of Archaeological Science 30(12): 1685-1693. doi: 10.1016/S0305$4403(03) 00070-0$

Philippsen B. 2015. Hard water and old food: the Freshwater reservoir effect in radiocarbon dating of food residues on pottery. Documenta Praehistorica 42: 159-170. doi: $10.4312 / \mathrm{dp} .42 .10$

Philippsen B., Heinemeier J. 2013. Freshwater reservoir effect variability in northern Germany. Radiocarbon 55 (2-3): 1085-1101. DOI: $10.2458 /$ azu_js_rc.55.16065

Piezonka H. 2008. Neue AMS-Daten zur frühneolitischen Keramikentwicklung in der nordosteuropäischen Waldzone. Estonian Journal of Archaeology 12(2): 67-113. doi: $10.3176 /$ arch.2008.2.01

2011. Rannyaya keramika k vostoku ot Baltiyskogo morya: Novye AMS radiouglerodnye daty. Tverskoy arkheologicheskiy sbornik 8(1): 159-174. (in Russian)

2015. Jäger, Fischer, Töpfer: Wildbeutergruppen mit früher Keramik in Nordosteuropa im 6. und 5. Jahrtausend v. Chr. Archäologie in Eurasien 30. Habelt. Bonn.

Piličiauskas G., Heron C. 2015. Aquatic radiocarbon reservoir offsets in the southeastern Baltic. Radiocarbon 57 (4): 539-556. doi: 10.2458/azu_rc.57.18447

Reimer P. J. and 25 co-authors. 2013. IntCal13 and marine13 radiocarbon age calibration curves $0-50,000$ years cal BP. Radiocarbon 55(4): 1869-1887. doi: 10.2458/ azu_js_rc.55.16947

Saarnisto M. (ed.) 2003. Karjalan synty: Viipurin läänin historia 1. Karjalan kirjapaino. Lappeenranta.

Saarnisto M., Vuorela I. 2007. Palaeogeography and palynology of Orov Navolok, NE Lake Onega. In L. G. Shayakhmetova (ed.), Kol'skiy sbornik. Institut istorii material'noy kul'tury Rossiyskaya Akademiya Nauk. Sankt-Peterburg: 82-101. (in Russian) 
Savvateev Yu. A., Devyatova E. I. and Liiva A. A. 1974. 0 datirovke pamyatnikov pervobytnoy epokhi v nizov'yakh r. Vyg. In Voprosy sovetskogo finno-ugrovedeniya: tezisy dokladov. Karel'skiy filial Akademii Nauk SSSR. Petrozavodsk: 31-33. (in Russian)

Seitsonen 0., Gerasimov D. V. 2008. Archaeological research in the Kurkijoki area in 2001 and 2003: a Preliminary study of the Stone Age settlement patterns in southern Ladoga Karelia. In M. Lavento, K. Nordqvist (eds.), Karelian Isthmus: Stone Age Studies in 1998-2003. Iskos 16. The Finnish Antiquarian Society. Helsinki: 164-184.

Seitsonen 0., Nordqvist K., Gerasimov D. V. and Lisitsyn S. N. 2012. 'The good, the bad, the weird': Stone Age and Early Metal Period radiocarbon dates and chronology from the Karelian Isthmus, north-west Russia. Geochronometria 39(2): 101-121. DOI: 10.2478/s13386-012-0001-9

Sidorov V. V. 1997. Vzglyad na mezolit i neolit Karelii iz Volgo-Okskogo mezhdurech'ya. In M. M. Shakhnovich (ed.), Arkheologiya Severa 1. Petrozavodsk: 96-109. (in Russian)

Skandfer M. 2011. 'All change?' Exploring the role of technological choice in the Early Northern Comb Ware of Finnmark, Arctic Norway. In P. Jordan, M. Zvelebil (eds.), Ceramics before Farming: the Dispersal of Pottery among Prehistoric Eurasian Hunter-Gatherers. Left Coast Press. Walnut Creek: 347-373.

Skorobogatov A. M., Smol'yaninov R. V., Surkov A. V., Oinonen M. and Possnert G. 2016. Khronologiya neoliticheskikh pamyatnikov lesostepnogo Podon'ya. In A. N. Mazurkevich, M. A. Kulkova and E. V. Dolbunova (eds.), Radiouglerodnaya khronologiya epokhi neolita Vostochnoy Evropy VII-III tysyacheletiya do n.e. Svitok. Smolensk: 244-260. (in Russian)

Smirnov A. S. 1991. Neolit verkhney $i$ sredney Desny. Institut Arkheologii Rossiyskaya Akademiya Nauk. Moskva. (in Russian)

1996. Neolit lesnogo Podesen'ya. In S. V. Oshibkina (ed.), Neolit Severnoy Evraziya. Arkheologiya. Nauka. Moskva: 202-205. (in Russian)

Smol'yaninov R. V. 2009. Keramika s rombo-yamochnoy ornamentatsiey lesostepnogo Podon'ya $\mathrm{v}$ sisteme romboyamochnykh keramicheskikh drevnostey Vostochnoy Evropy. Tverskoy arkheologicheskiy sbornik 7: 257-274. (in Russian)

2013. Poselenie Karamyshevo 19 na verkhnem Donu. Tverskoy arkheologicheskiy sbornik 9: 232-248. (in Russian)
Takala H., Shakhnovich M. M., Malinen A. and Tarasov A. Yu. 2016. New Stone Age sites to the north of Lake Ladoga in Karelia, Russia. In P. Uino, K. Nordqvist (eds.), New Sites, New Methods. Iskos 21. The Finnish Antiquarian Society. Helsinki: 24-40.

Tarasov A. Yu. 2008. Novye dannye po pozdnemu i final'nomu mezolitu severo-zapadnogo Pribelomor'ya. In A. P. Derevyanko, N. A. Makarov (eds.), Trudy II (XVIII) Vserossiyskogo arkheologicheskogo s'ezda v Suzdale 2008 g: Tom 8. Institut Arkheologii Rossiyskaya Akademiya Nauk. Moskva: 165-166. (in Russian)

2015. Fofanovo XIII: Primer intensivnoy proizvodstvennoy deyatel'nosti epokhi rannego metalla $\mathrm{v}$ lesnoy zone. In G. A. Khlopachev (ed.), Drevnie kul'tury Vostochnoj Evropy: Etalonnye pamyatniki i opornye kompleksy $v$ kontekste sovremennykh arkheologicheskikh issledovaniy. Zamyatninskiy sbornik 4 . Muzey antropologii i etnografii im. Petra Velikogo (Kunstkamera) Rossiyskaya Akademiya Nauk. Sankt-Peterburg: 307-317. (in Russian)

Tarasov A. Yu., Khoroshun T. A. 2016. Radiouglerodnaya khronologiya perioda neolita i eneolita na territorii Karelii. In A. N. Mazurkevich, M. A. Kulkova and E. V. Dolbunova (eds.), Radiouglerodnaya khronologiya epokhi neolita Vostochnoy Evropy VII-III tysyacheletiya do n.e. Svitok. Smolensk: 368-387. (in Russian)

Timofeev V. I., Zaytseva G. I., Dolukhanov P. M. and Shukurov A. M. 2004. Radiouglerodnaya khronologiya neolita Severnoy Evrazii. Teza. Sankt-Peterburg. (in Russian)

Torvinen M. 1999. Jokkavaara: an Early ceramic settlement site in Rovaniemi, North Finland. In M. Huurre (ed.), Dig It All: Papers Dedicated to Ari Siiriäinen. The Finnish Antiquarian Society, The Archaeological Society of Finland. Helsinki: 225-240.

Torvinen M. 2000. Säräisniemi I Ware. Fennoscandia Archaeologica XVII: 3-35. http://www.sarks.fi/fa/faxvii.html

Vereshchagina I. V. 2003. Poselenie Khepo-yarvi v yuzhnoy chasti Karel'skogo peresheyka. In V. I. Timofeev, G. V. Sinitsyna (eds.), Heolit - eneolit yuga i neolit severa Vostochnoy Evropy. Institut istorii material'noy kul'tury Rossiyskaya Akademiya Nauk. Sankt-Peterburg: 140-151. (in Russian)

Vitenkova I. F. 1986. Poselenie Lakshezero II s chistym kompleksom grebenchato-yamochnoy keramiki. In S. I. Kochkurkina (ed.), Novye dannye ob arkheologicheskikh pamyatnikakh Karelii. Karel'skiy filial Akademii Nauk SSSR. Petrozavodsk: 119-138. (in Russian) 
1996. Kul'tura sperrings. In M. G. Kosmenko, S. I. Kochkurkina (eds.), Arkheologiya Karelii. Karel'iskiy nauchniy tsentr Rossiyskaya Akademiya Nauk. Petrozavodsk: 65-81. (in Russian)

2002. Pamyatniki pozdnego neolita na territorii $\mathrm{Ka}$ relii. Karel'skiy nauchniy tsentr Rossiyskaya Akademiya Nauk. Petrozavodsk. (in Russian)

2009. Adaptatsiya naseleniya pozdnego neolita i eneolita k prirodnym usloviyam Karelii. In M. G. Kosmenko (ed.), Adaptatsiya kul'tury naseleniya Karelii $k$ osobennostyam mestnoy prirodnoy sredy periodov mesolita - srednevekov'ya. Karel'iskiy nauchniy tsentr Rossiyskaya Akademiya Nauk. Petrozavodsk: 69-97. (in Russian)

2016. Kareliya $v$ nachale epokhi metalla (pamyatniki s rombo-yamochnoy keramikoy). Karel'iskiy nauchniy tsentr Rossiyskaya Akademiya Nauk. Petrozavodsk. (in Russian)

Yanits L. Yu. 1959. Poseleniya epokhi neolita i rannego metalla v priust'e r. Emayigi (Estonskaya SSR). Institut istorii Akademii Nauk ESSR. Tallin. (in Russian)

Zaretskaya N. E., Kostyleva, E. L. 2011. Novye dannye po absolyutnoy khronologii l'yalovskoy kul'tury. Tverskoy arkheologicheskiy sbornik 8(1): 175-183. (in Russian)

Zhul'nikov A. M. 1991. Problemy khronologii i periodizatsii pozdnego eneolita Karelii. In S. I. Kochkurkina (ed.), Khronologiya $i$ periodizatsiya arkheologicheskikh pamyatnikov Karelii. Karel'iskiy nauchniy tsentr Rossiyskaya Akademiya Nauk. Petrozavodsk: 126-146. (in Russian)

1999. Eneolit Karelii. Karel'skiy nauchniy tsentr Rossiyskaya Akademiya Nauk. Petrozavodsk. (in Russian)

2005. Poseleniya epokhi rannego metalla yugo-zapadnogo Pribelomory'a. Paritet. Petrozavodsk. (in Russian)

2007. Pamyatniki s keramikoy typa Zalavruga I v Pribelomor'e i nekotorye voprosy izucheniya belomorskikh petroglifov. In L. G. Shayakhmetova (ed.), Kol'skiy sbor- $n i k$. Institut istorii material'noy kul'tury Rossiyskaya Akademiya Nauk. Sankt-Peterburg: 102-137. (in Russian)

Zhul'nikov A. M., Tarasov A. Yu. 2014. K voprosu o keramike 'perekhodnogo' typa (po materialam poseleniya Fofanovo XIII). In H. M. Abdullin, A. P. Derevyanko, N. A. Makarov and A. G. Sitdikov (eds.), Trudy IV (XX) Vserossiyskogo arkheologicheskogo s'ezda v Kazani 2014 g: Tom 1. Institut Arkheologii AN RT, Kazanskiy (Privolzhskiy) Federal'niy Universitet, Institut Arkheologii Rossiyskaya Akademiya Nauk, Institut Arkheologii i Etnografii So Rossiyskaya Akademiya Nauk. Kazan: 259-260. (in Russian)

Zhulnikov A., Tarasov A. and Kriiska A. 2012. Discrepancies between conventional and AMS dates of complexes with Asbestos and Porous Ware: Probable result of 'reservoir effect'. Fennoscandia Archaeologica XXIX: 79-86. http://www.sarks.fi/fa/faxxix.html

Zhuravlev A. P. 1976. Raboty Karel'skogo muzeya. In $A r$ kheologicheskie otkrytiya 1975 goda. Nauka. Moskva: 14-15. (in Russian)

1977. Eneolit Karelii. Unpublished candidate's dissertation. Karel'skiy filial Akademii Nauk SSSR. Petrozavodsk. (in Russian)

1979. Eneoliticheskiy etap v karelskoy arkheologicheskoy kul'ture i problema ego datirovki. Kratkie Soobshcheniya Instituta Arkheologii 157: 82-86. (in Russian)

1984. Datirovka poseleniy mezolita - rannego metalla v Unitskoy Gube Onezhskogo ozera. Sovetskaya Arkheologiya 1984(4): 119-126. (in Russian)

1991. Pegrema (poseleniya epokhi eneolita). Karel'skiy nauchniy tsentr Rossiyskaya Akademiya Nauk. Petrozavodsk. (in Russian)

Zhuravlev A. P., Liiva A. A. 1980. 0 datirovke arkheologicheskikh pamyatnikov v Pegreme (Kareliya). Geokhronologiya chetvertichnogo perioda. Nauka. Moskva: 40-44. (in Russian) 


\begin{tabular}{|c|c|c|c|c|c|c|c|c|c|c|c|c|}
\hline 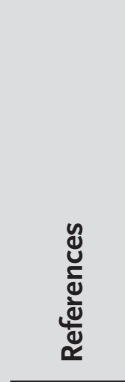 & 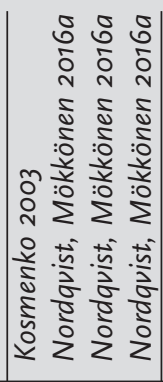 & 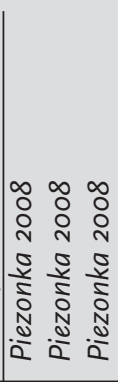 & 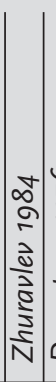 & 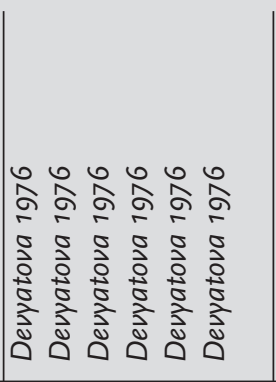 & 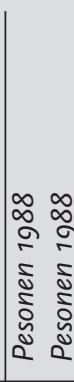 & 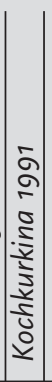 & 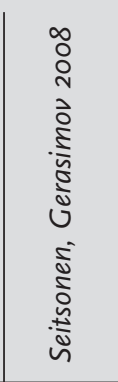 & 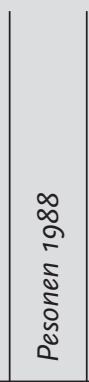 & 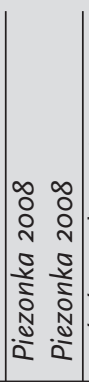 & 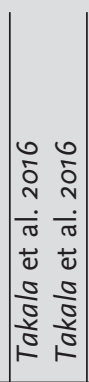 & 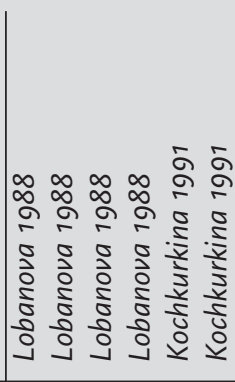 & 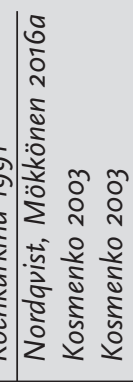 \\
\hline 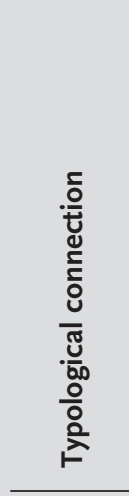 & 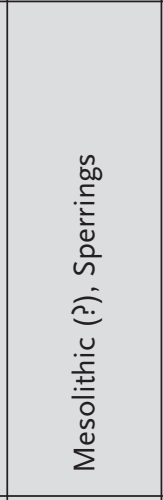 & 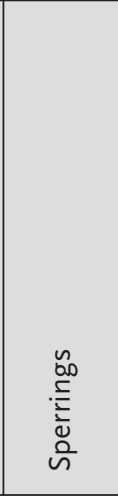 & 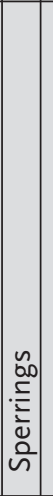 & 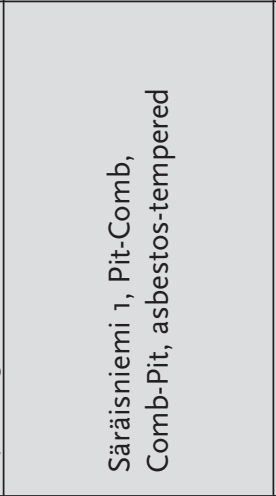 & 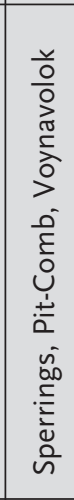 & 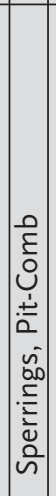 & 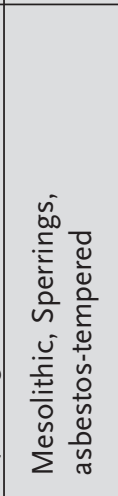 & 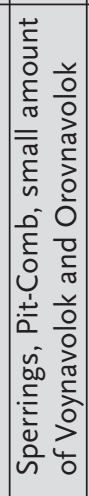 & 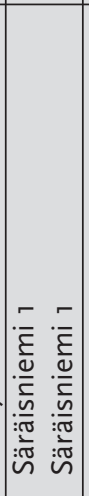 & 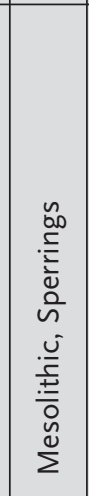 & 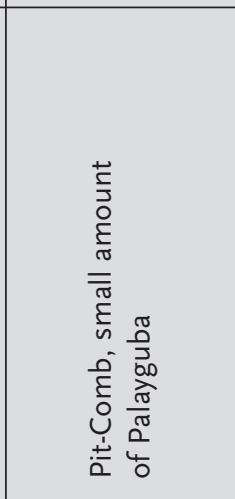 & 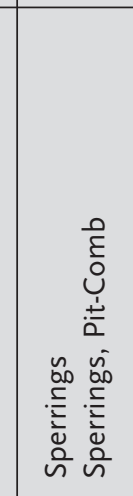 \\
\hline 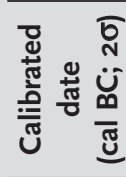 & 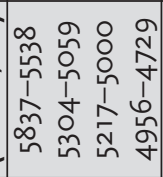 & 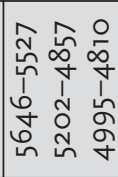 & 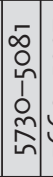 & 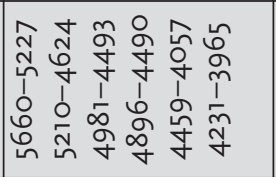 & 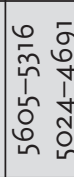 & 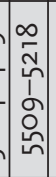 & $\begin{array}{l}\text { a } \\
\text { ơ } \\
1 \\
\frac{1}{\sigma} \\
6 \\
0\end{array}$ & $\begin{array}{l}\text { N } \\
\text { D } \\
\stackrel{1}{1} \\
\infty \\
\text { W } \\
\text { in }\end{array}$ & 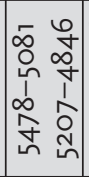 & 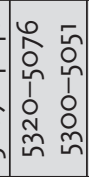 & 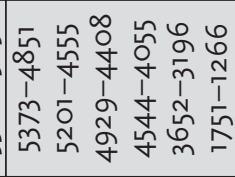 & 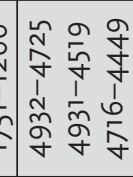 \\
\hline 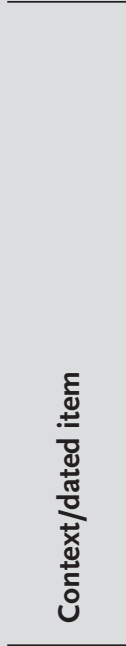 & 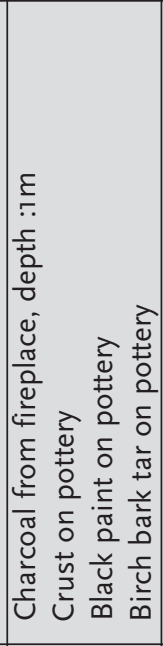 & 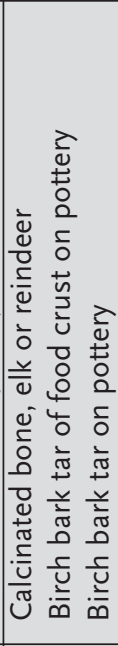 & 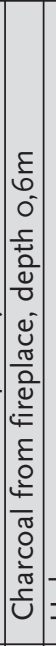 & 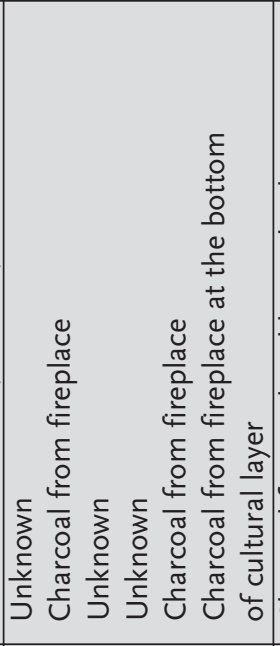 & 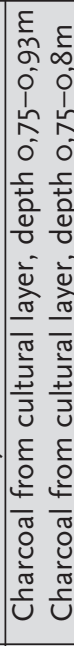 & $\mid$ & 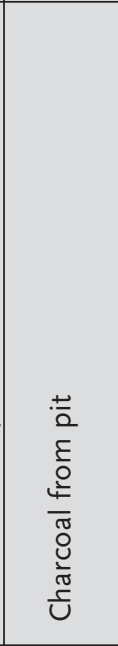 & 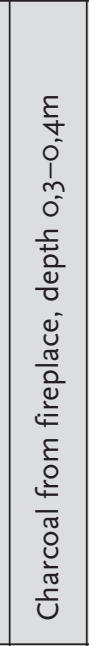 & 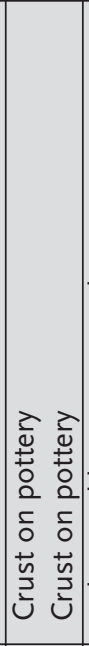 & 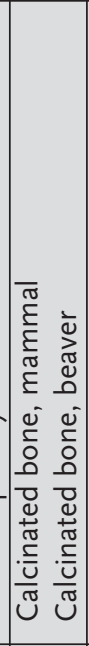 & 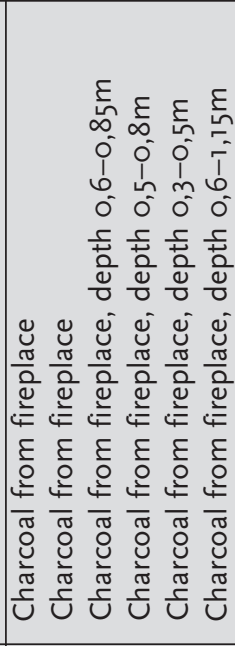 & 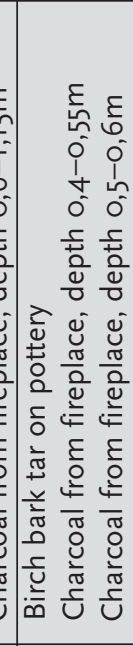 \\
\hline 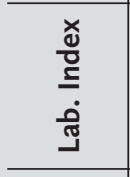 & 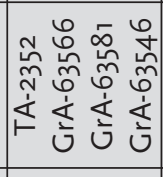 & 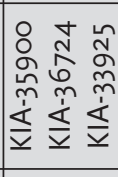 & $\frac{\bar{\sigma}}{\frac{\overline{1}}{\mathbf{T}}}$ & 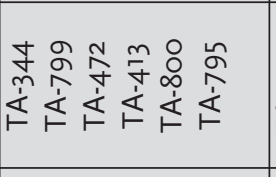 & 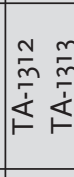 & 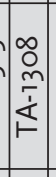 & 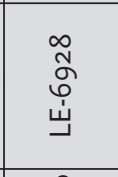 & 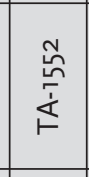 & 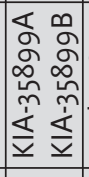 & 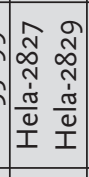 & 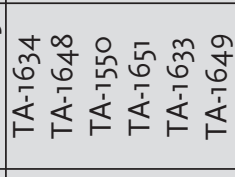 & 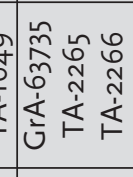 \\
\hline 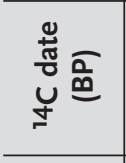 & 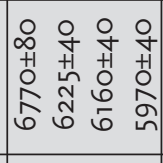 & $\begin{array}{lll}n & 0 & 0 \\
m & m & 0 \\
+1 & +1 & +1 \\
0 & \infty & 4 \\
0 & 0 & 0 \\
0 & 0 & 0\end{array}$ & 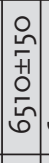 & 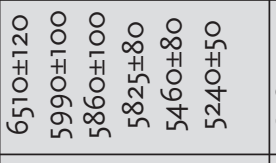 & 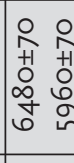 & & $\begin{array}{l}8 \\
8 \\
0 \\
+1 \\
0 \\
0 \\
0 \\
0\end{array}$ & 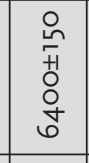 & $\begin{array}{|ll|}0 & 0 \\
0 & f \\
+1 & +1 \\
0 & 0 \\
0 & 0 \\
0 & 0 \\
0\end{array}$ & 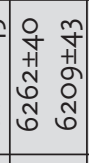 & 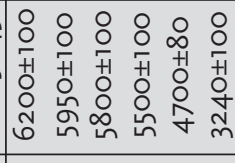 & 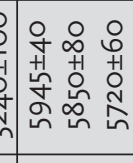 \\
\hline$\stackrel{\Perp}{*}$ & 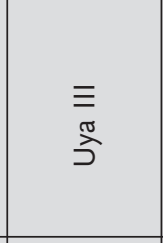 & $\begin{array}{l}\overline{\bar{J}} \\
\frac{\vec{b}}{\vec{\omega}} \\
\bar{\omega}\end{array}$ & 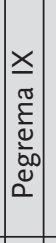 & 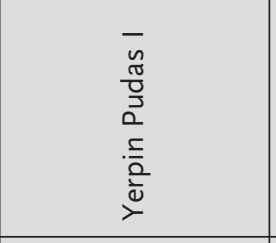 & 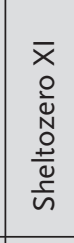 & $\begin{array}{c}x \\
0 \\
\frac{2}{2} \\
0 \\
0 \\
\frac{1}{d} \\
\frac{2}{n}\end{array}$ & 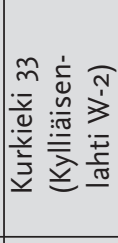 & 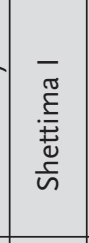 & 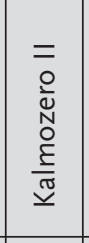 & 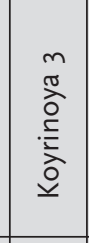 & 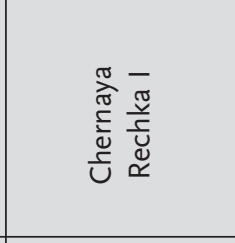 & 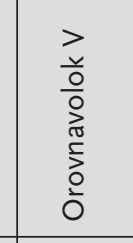 \\
\hline$\dot{\dot{z}} \delta \stackrel{\text { ๓े }}{\xi}$ & r & $m$ & $|N|$ & $=$ & $\infty$ & & $\widehat{\imath}$ & $\wedge$ & 6 & $\stackrel{\bullet}{N}$ & $\stackrel{\circ}{\circ}$ & $\sigma$ \\
\hline
\end{tabular}




\begin{tabular}{|c|c|c|c|c|c|c|c|c|c|c|c|c|}
\hline 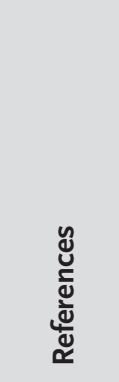 & 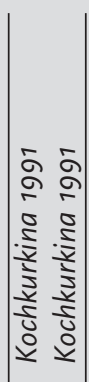 & 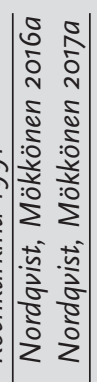 & $\mid \begin{array}{l} \\
\\
\infty \\
0 \\
0 \\
0 \\
0 \\
0 \\
0 \\
0 \\
0 \\
0\end{array}$ & 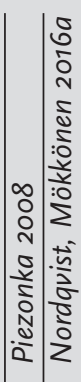 & 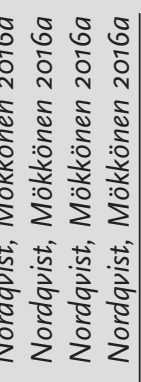 & 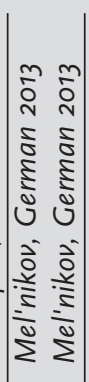 & 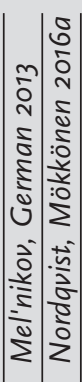 & 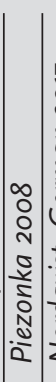 & 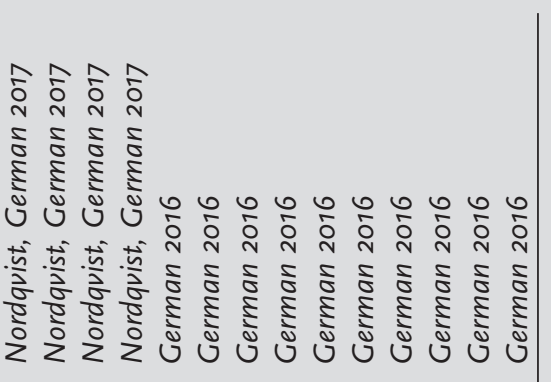 & 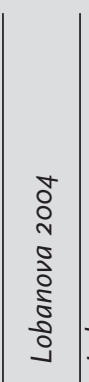 & 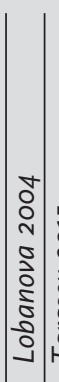 & 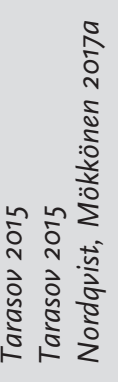 \\
\hline 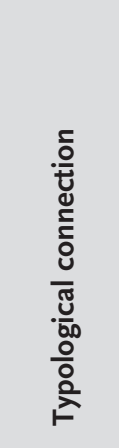 & $\begin{array}{l}\stackrel{0}{E} \\
\stackrel{0}{0} \\
\stackrel{+}{*}\end{array}$ & 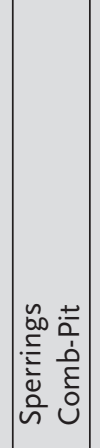 & 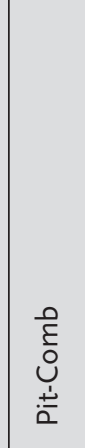 & 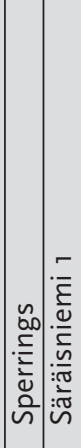 & 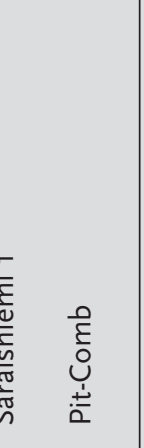 & 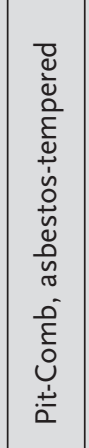 & 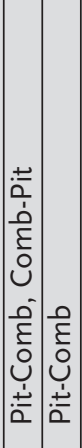 & 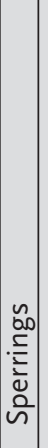 & 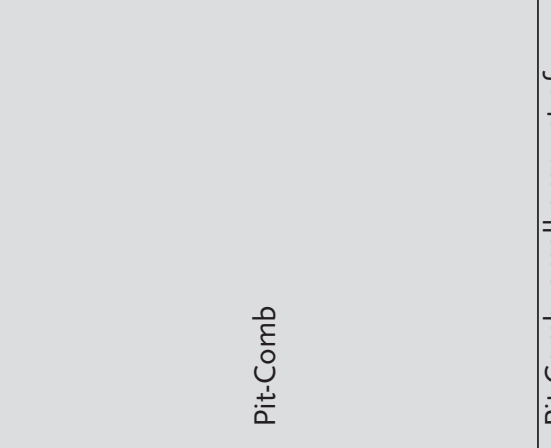 & 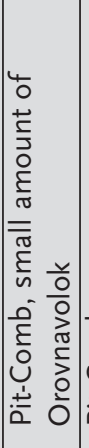 & 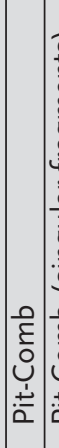 & 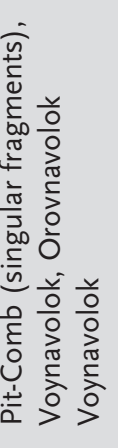 \\
\hline 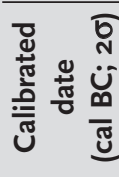 & 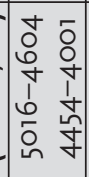 & 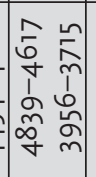 & $\begin{array}{l}\sigma \\
\frac{\sigma}{j} \\
\frac{1}{\tilde{g}} \\
\frac{q}{q}\end{array}$ & 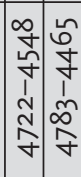 & 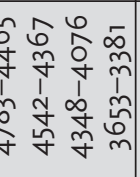 & 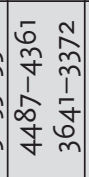 & 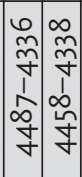 & 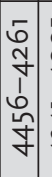 & 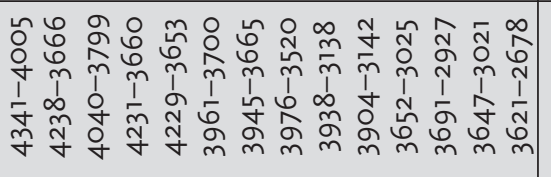 & 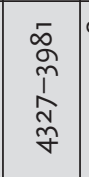 & 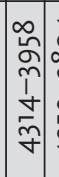 & 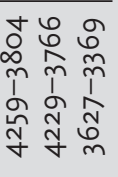 \\
\hline 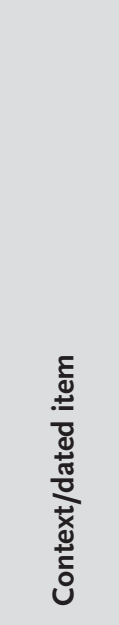 & 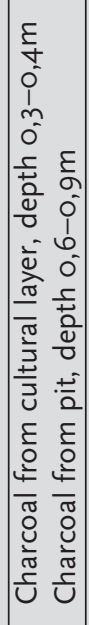 & 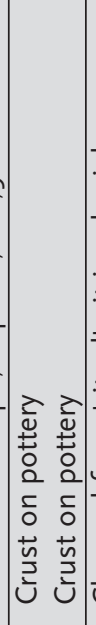 & 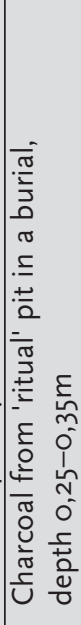 & 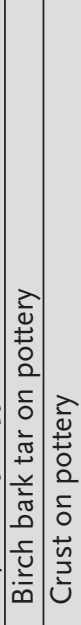 & 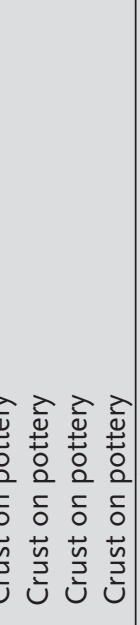 & 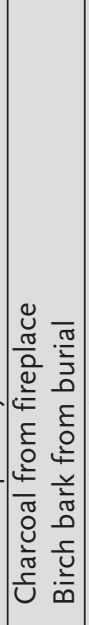 & 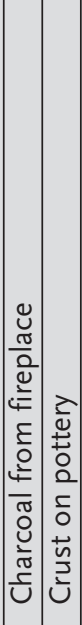 & 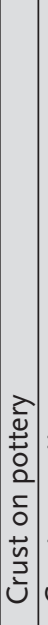 & 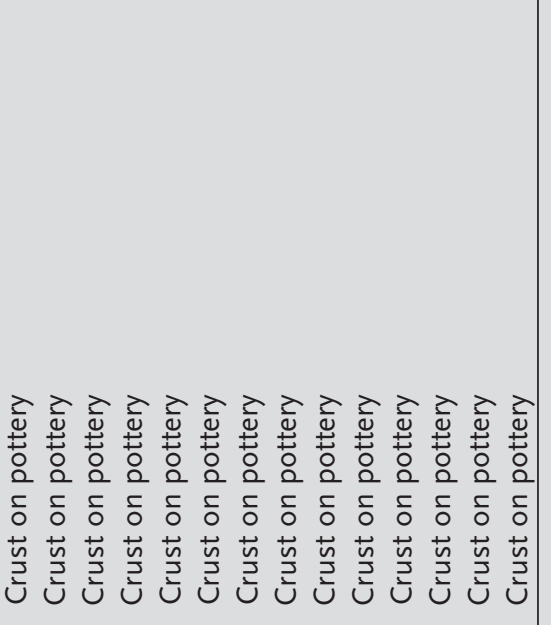 & 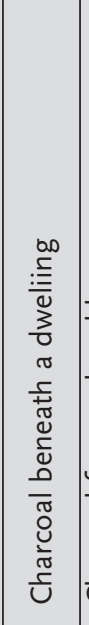 & 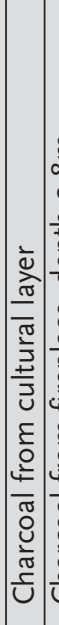 & 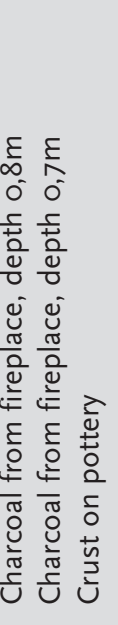 \\
\hline 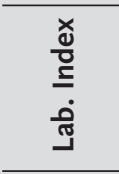 & 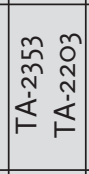 & 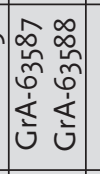 & 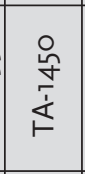 & 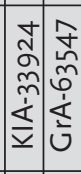 & 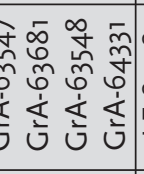 & 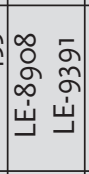 & 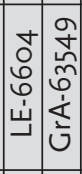 & 立 & 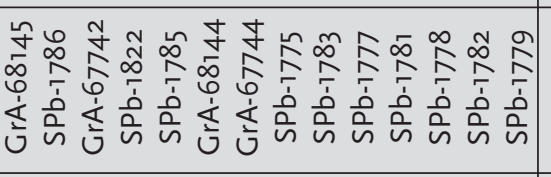 & 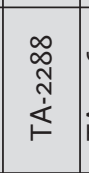 & 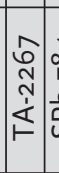 & 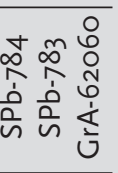 \\
\hline 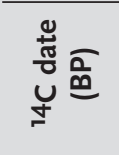 & 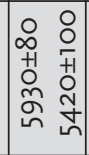 & 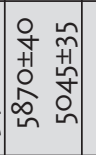 & \begin{tabular}{c|c|}
$\infty$ \\
$\infty$ \\
0 \\
0 \\
0 \\
$\infty$ \\
$\infty$
\end{tabular} & 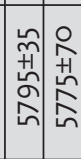 & 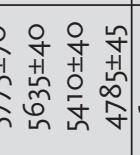 & 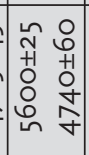 & 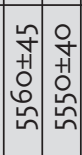 & 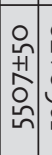 & 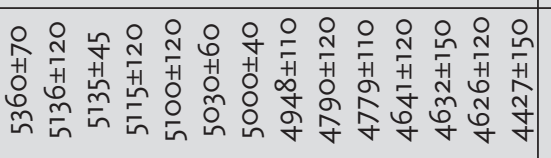 & \begin{tabular}{|l|} 
\\
$\infty$ \\
+1 \\
$\circ$ \\
$\stackrel{n}{n}$ \\
\end{tabular} & \begin{tabular}{|l|l}
0 \\
0 \\
+1 \\
+1 \\
0 \\
0 \\
1 \\
1
\end{tabular} & 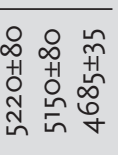 \\
\hline$\stackrel{ \pm}{\dot{\omega}}$ & 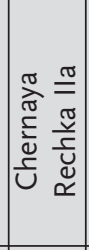 & 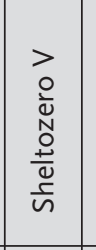 & 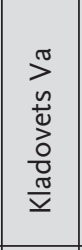 & 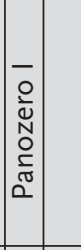 & 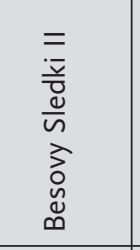 & 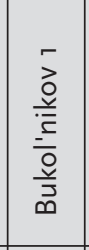 & 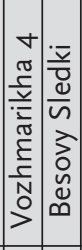 & & 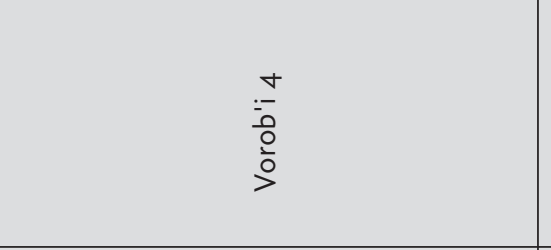 & $\begin{array}{l}x \\
\frac{x}{0} \\
\frac{0}{0} \\
\frac{0}{0} \\
\frac{\pi}{\underline{v}}\end{array}$ & 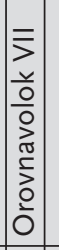 & 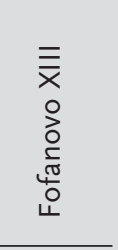 \\
\hline$\dot{\dot{z}}$ ¿ $\stackrel{\text { ๓ิ }}{\xi}$ & $\stackrel{\circ}{\circ}$ & $\infty$ & $\circ$ & | & $=$ & +1 & $|A|=\mid$ & & + & $\therefore$ & |al & $\stackrel{n}{n}$ \\
\hline
\end{tabular}




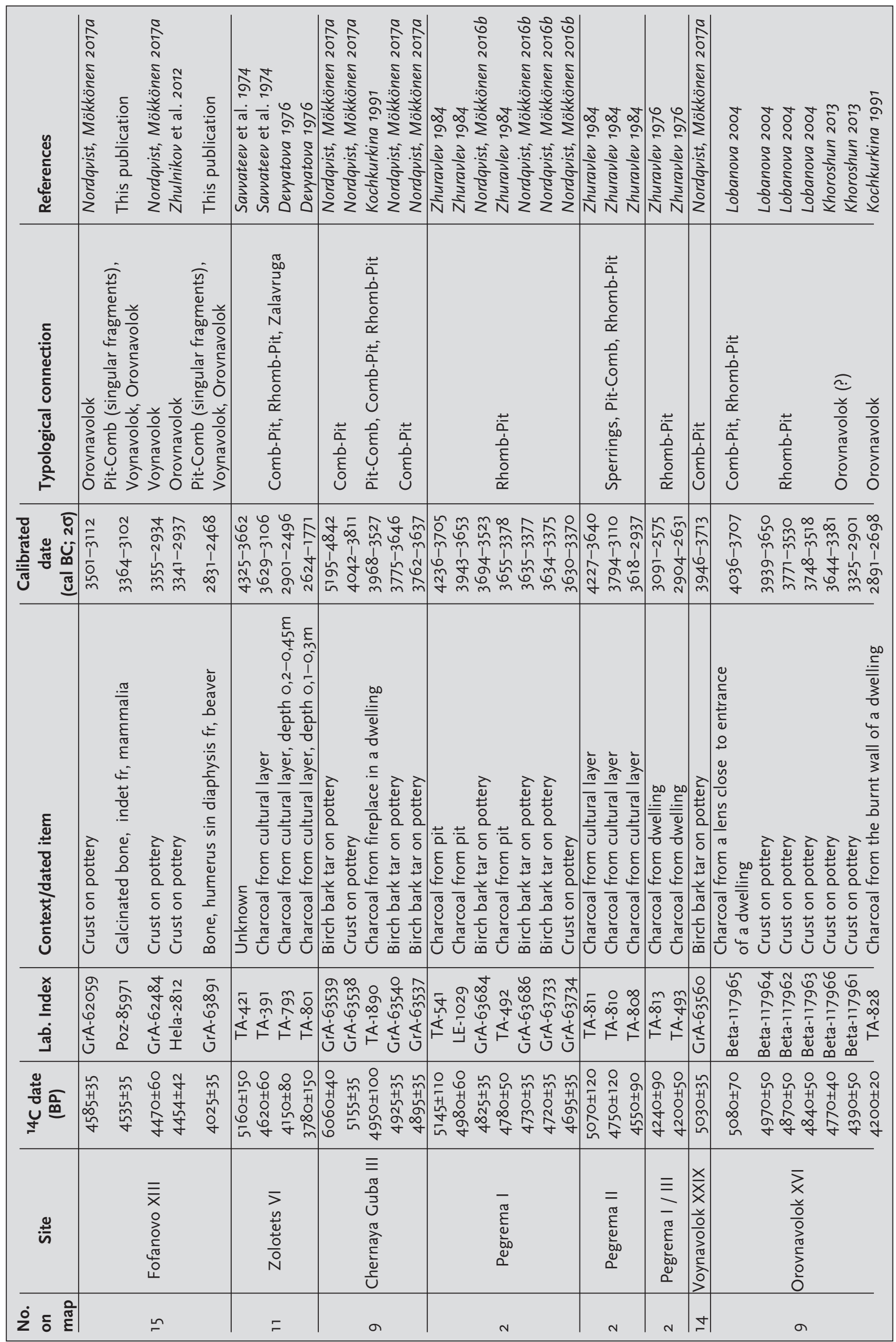




\begin{tabular}{|c|c|c|c|c|c|c|c|c|c|c|c|c|c|c|c|}
\hline \multirow[b]{2}{*}{ 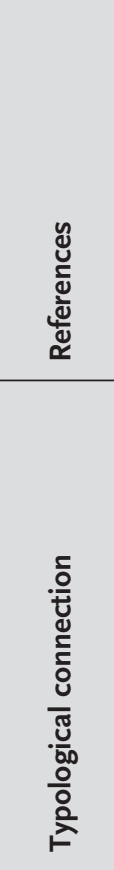 } & \multirow[b]{2}{*}{ 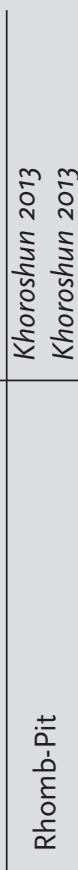 } & 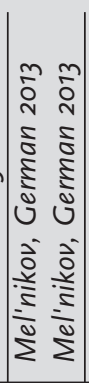 & 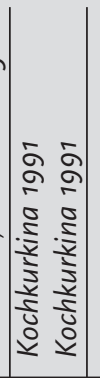 & 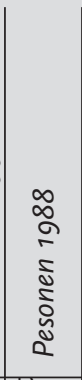 & \multicolumn{4}{|c|}{ 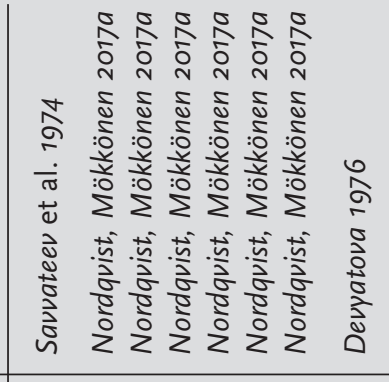 } & \multicolumn{2}{|l|}{ 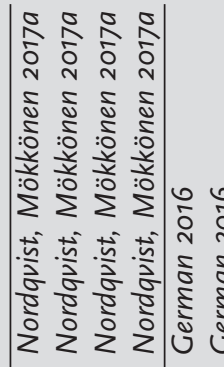 } & 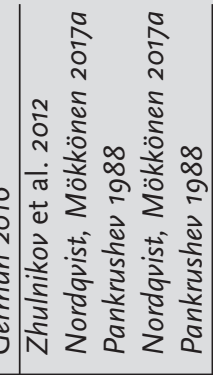 & \multicolumn{3}{|c|}{ 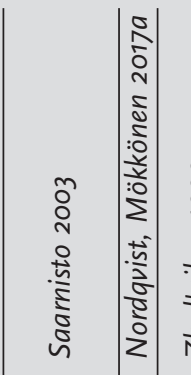 } & 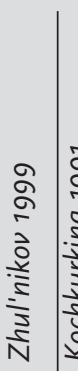 \\
\hline & & $\mid$ & 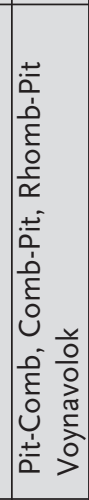 & 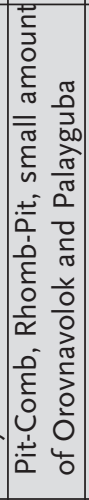 & $\begin{array}{ll} \\
\\
\\
0\end{array}$ & 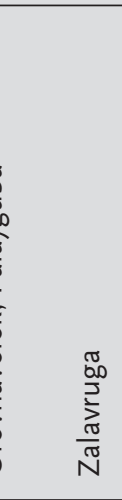 & 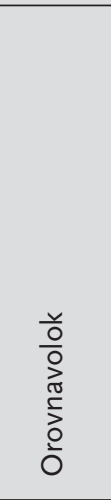 & 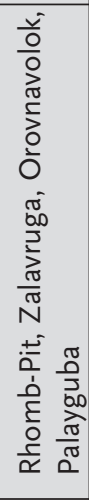 & 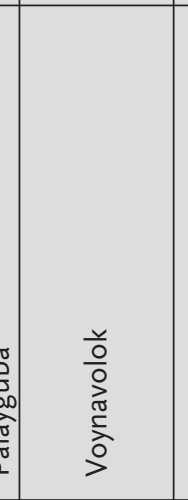 & $\begin{array}{l}\frac{\vec{t}}{\dot{0}} \\
\text { हे } \\
\text { हे }\end{array}$ & 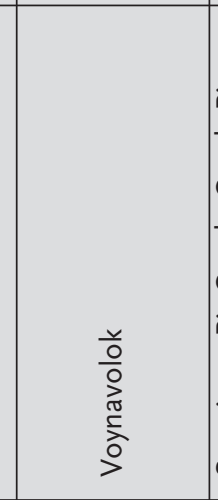 & 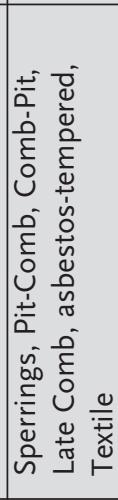 & 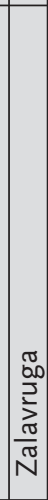 & 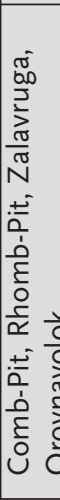 & 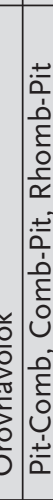 \\
\hline 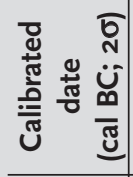 & 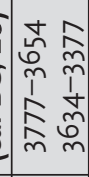 & 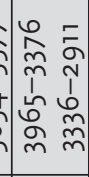 & 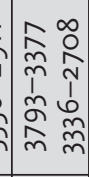 & $\begin{array}{l}\mathfrak{o} \\
\hat{n} \\
1 \\
o \\
o \\
m\end{array}$ & 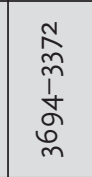 & 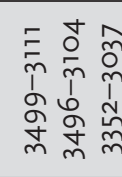 & 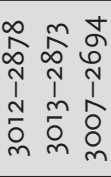 & & 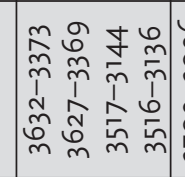 & 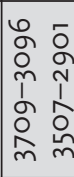 & 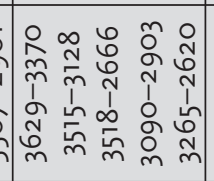 & $\begin{array}{l}o \\
o \\
\tilde{o} \\
o \\
\tilde{N} \\
\text { n}\end{array}$ & $\begin{array}{l}0 \\
m \\
\tilde{n} \\
\hat{b} \\
\tilde{\omega} \\
m\end{array}$ & 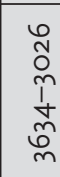 & $\begin{array}{l}0 \\
0 \\
0 \\
1 \\
-1 \\
\end{array}$ \\
\hline 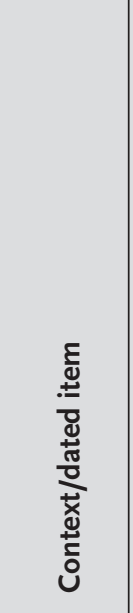 & 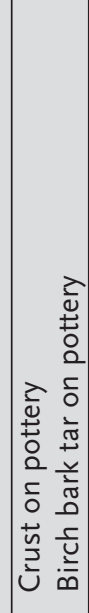 & 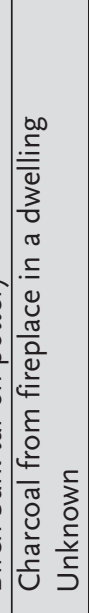 & 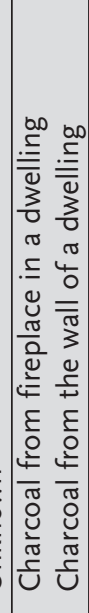 & 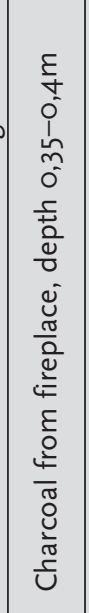 & 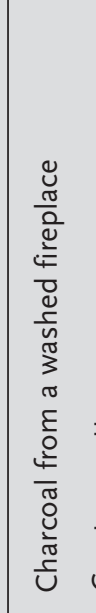 & 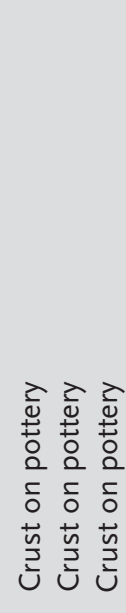 & 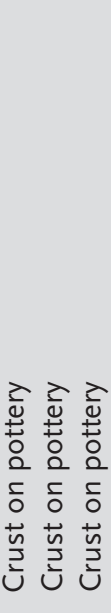 & 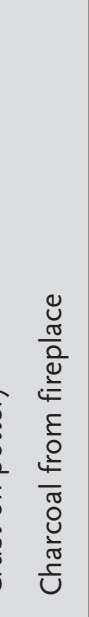 & 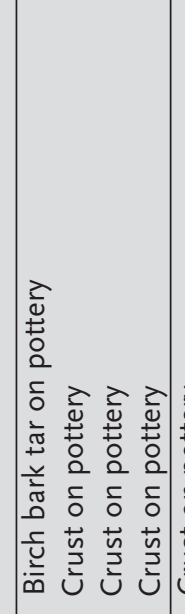 & 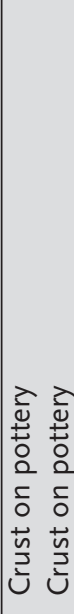 & 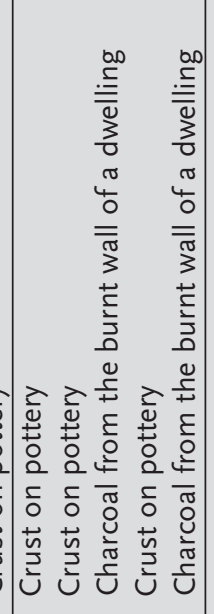 & 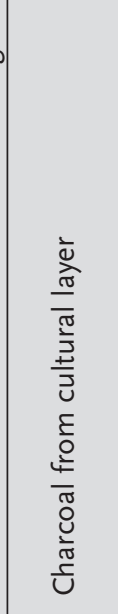 & 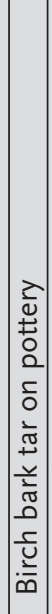 & 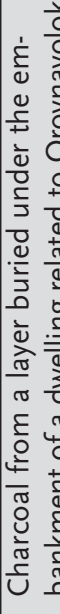 & 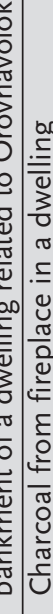 \\
\hline 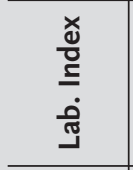 & 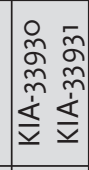 & $\hat{n}$ & 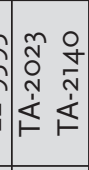 & 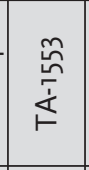 & 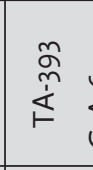 & 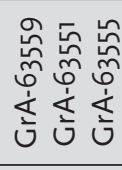 & 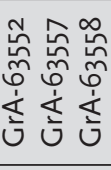 & $\frac{O}{i}$ & 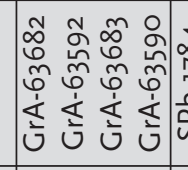 & 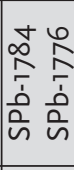 & 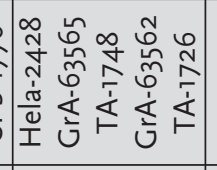 & $\begin{array}{l}\bar{n} \\
\stackrel{N}{1} \\
\stackrel{i}{n}\end{array}$ & $\begin{array}{l}0 \\
0 \\
\hat{\omega} \\
\hat{0} \\
\dot{1} \\
\vdots \\
v \\
\end{array}$ & 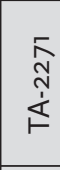 & . \\
\hline 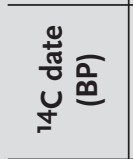 & 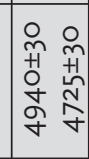 & $\left|\begin{array}{ll}0 & 0 \\
m & 0 \\
++1 & 0 \\
0 & 0 \\
0 & 0 \\
g & y \\
y & 7\end{array}\right|$ & \begin{tabular}{ll}
0 & 0 \\
0 & 0 \\
1 & 1 \\
0 & 0 \\
0 & 0 \\
0 & - \\
\hdashline & 9
\end{tabular} & $=\begin{array}{l}0 \\
0 \\
0 \\
0 \\
\infty \\
\infty \\
+\end{array}$ & 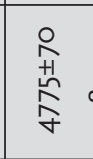 & 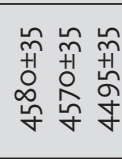 & 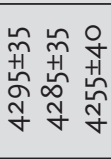 & 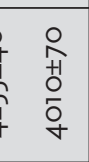 & 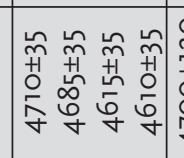 & 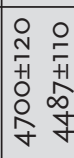 & 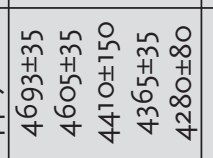 & 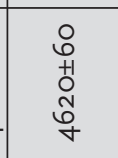 & $\begin{array}{l}0 \\
2 \\
+1 \\
0 \\
0 \\
\dot{y}\end{array}$ & $\begin{array}{l}8 \\
8 \\
+1 \\
0 \\
8 \\
6 \\
4\end{array}$ & $\begin{array}{l}0 \\
6 \\
+1 \\
0 \\
0 \\
0 \\
4\end{array}$ \\
\hline$\stackrel{g}{\Delta}$ & 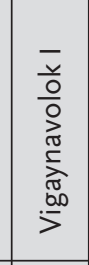 & 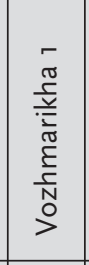 & 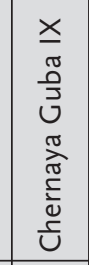 & 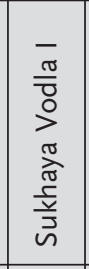 & & t & & & 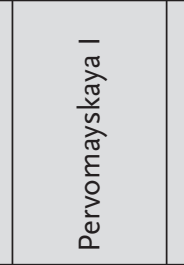 & 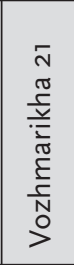 & 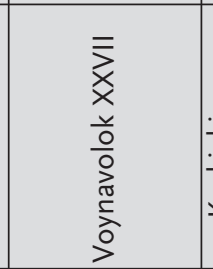 & 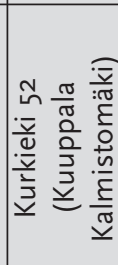 & $\begin{array}{l}x \\
x \\
0 \\
0 \\
0 \\
0 \\
N \\
N\end{array}$ & 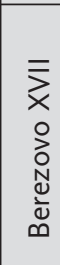 & 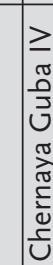 \\
\hline$\dot{\dot{z}} \delta \stackrel{\text { है }}{\mathrm{m}}$ & $\mid$ & 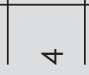 & $a$ & $m$ & & & & & 4 & 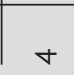 & \pm & $\hat{N}$ & $=$ & 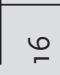 & \\
\hline
\end{tabular}




\begin{tabular}{|c|c|c|c|c|c|c|c|c|c|c|c|c|c|c|c|}
\hline 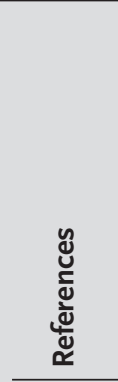 & 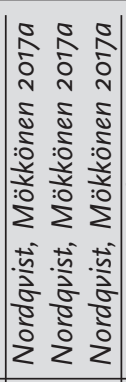 & 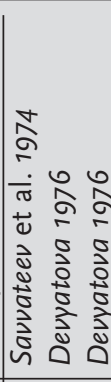 & 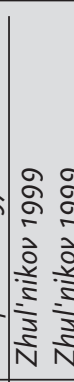 & 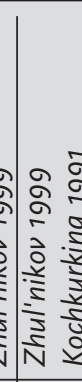 & 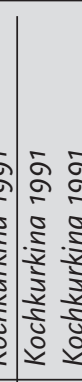 & 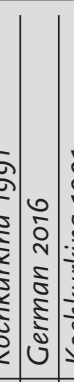 & 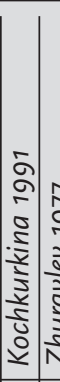 & 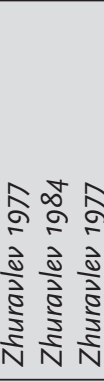 & 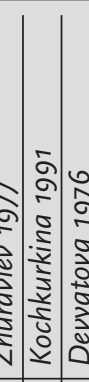 & 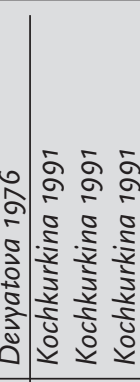 & 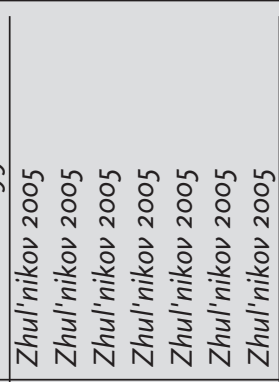 & 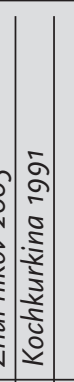 & 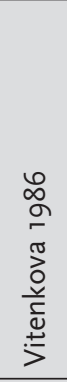 & & 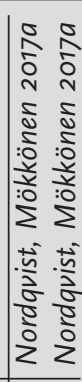 \\
\hline 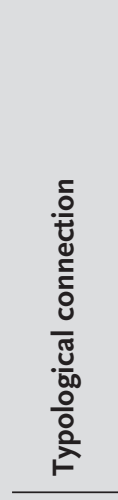 & 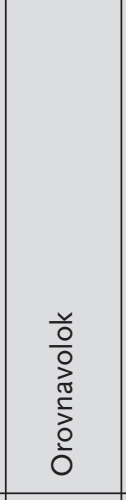 & 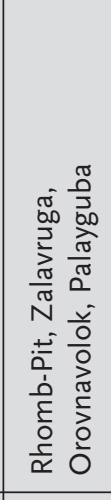 & 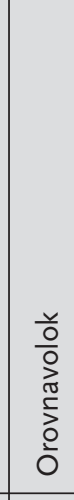 & $\begin{array}{l}\frac{}{0} \\
0 \\
\frac{0}{0} \\
\sum_{0}^{0} \\
0 \\
0\end{array}$ & 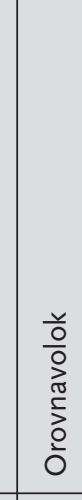 & 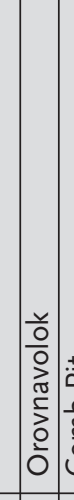 & 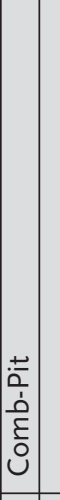 & 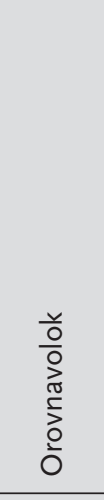 & 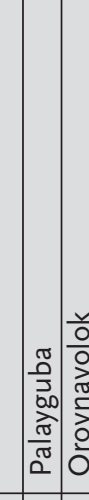 & 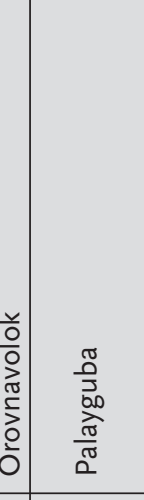 & $\begin{array}{l}\frac{\pi}{0} \\
\frac{0}{\sqrt[0]{0}} \\
\frac{\pi}{\sigma} \\
0\end{array}$ & 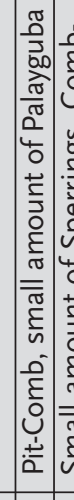 & 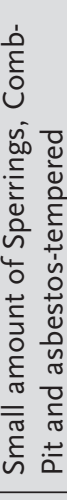 & 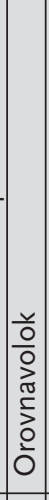 & 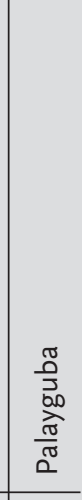 \\
\hline 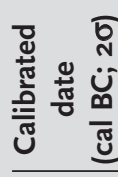 & 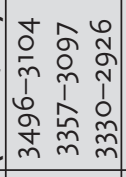 & 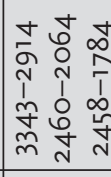 & $\mid \begin{array}{ll}\infty & \infty \\
\infty & 0 \\
\infty & 0 \\
N & n \\
1 & 1 \\
0 & 1 \\
m & n \\
m & n\end{array}$ & 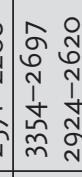 & 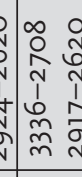 & & 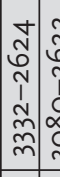 & 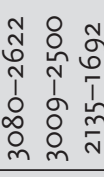 & 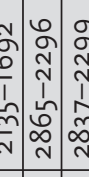 & 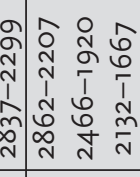 & 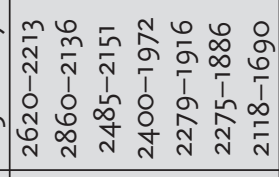 & 2. & 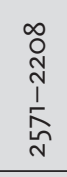 & 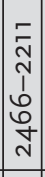 & 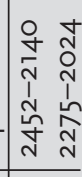 \\
\hline 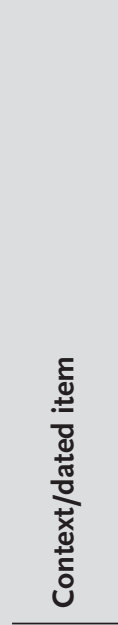 & 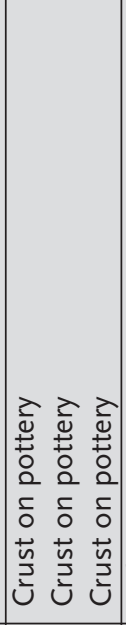 & 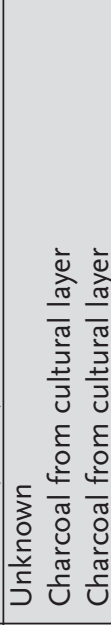 & 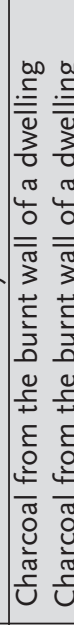 & 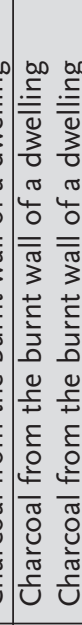 & 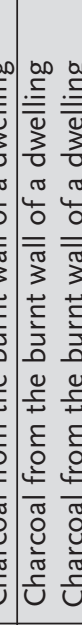 & 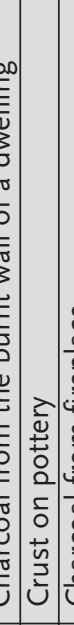 & 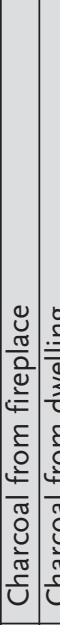 & 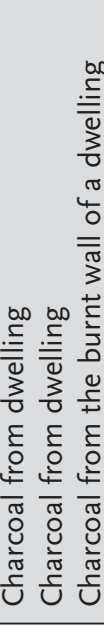 & 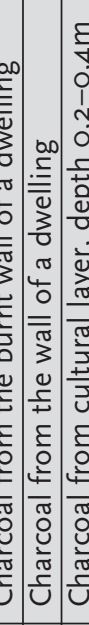 & 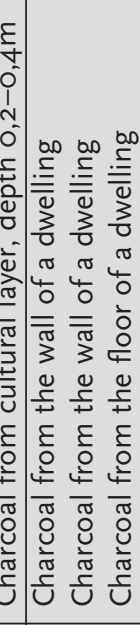 & 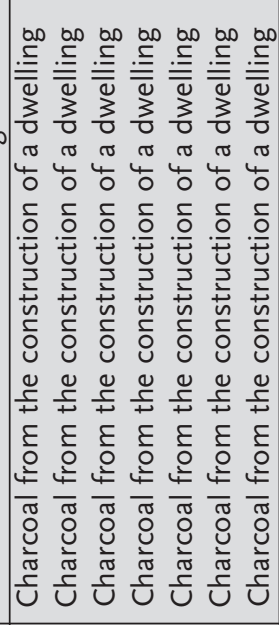 & 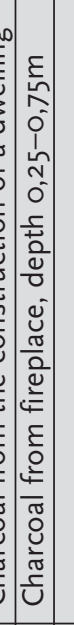 & 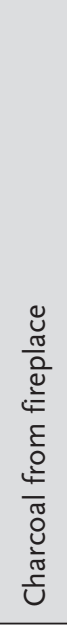 & 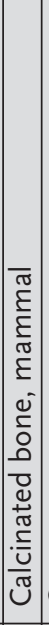 & 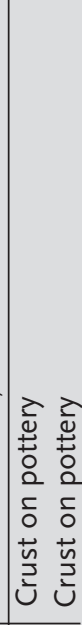 \\
\hline 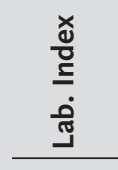 & 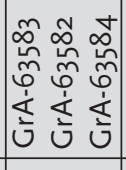 & 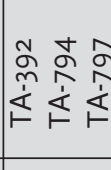 & 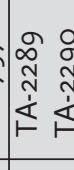 & 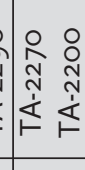 & 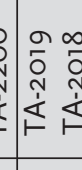 & 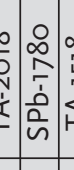 & 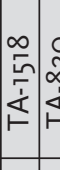 & 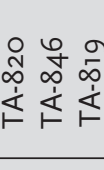 & 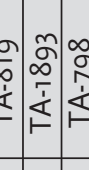 & 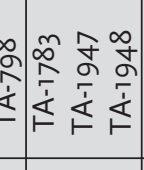 & 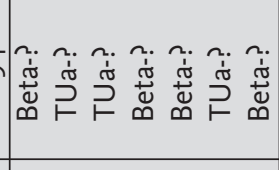 & 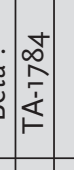 & 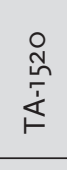 & 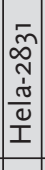 & 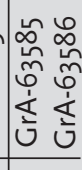 \\
\hline 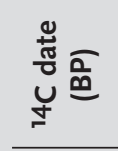 & 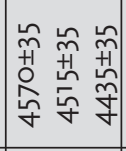 & \begin{tabular}{lll}
0 & 0 & 0 \\
$\infty$ & 0 & 0 \\
+1 & +1 & +1 \\
0 & 0 & +1 \\
$m$ & 0 & 0 \\
$f$ & $\infty$ & 0 \\
\cline { 1 - 1 } & 0 & 0
\end{tabular} & $\mid$\begin{tabular}{ll}
0 & 0 \\
0 & 0 \\
+1 & +1 \\
0 & 0 \\
0 & 0 \\
& 0 \\
\cline { 1 - 1 }
\end{tabular} & 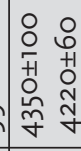 & 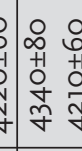 & 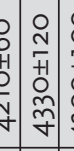 & 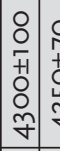 & 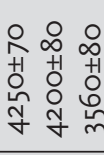 & 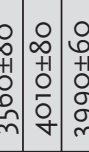 & 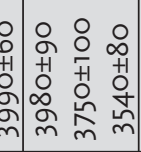 & 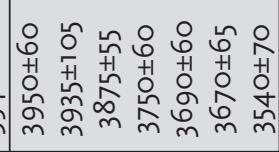 & 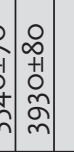 & $\begin{array}{l}0 \\
0 \\
+1 \\
0 \\
\text { N } \\
\text { r }\end{array}$ & $\mid \begin{array}{c}m \\
m \\
0 \\
0 \\
0 \\
m \\
m\end{array}$ & 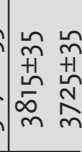 \\
\hline$\stackrel{\Xi}{\dot{n}}$ & $\begin{array}{l}\vec{x} \\
\frac{\pi}{0} \\
\frac{0}{00} \\
\stackrel{5}{5} \\
⺊\end{array}$ & 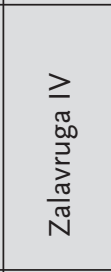 & 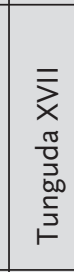 & $\begin{array}{l}\equiv \\
\equiv \\
\frac{\pi}{0} \\
\frac{0}{00} \\
\frac{5}{J} \\
⺊\end{array}$ & 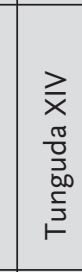 & 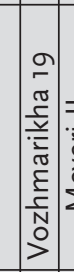 & $\begin{array}{l}= \\
= \\
\bar{c} \\
\bar{a} \\
\frac{a}{2} \\
\Sigma\end{array}$ & 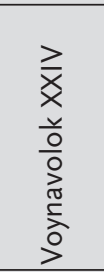 & 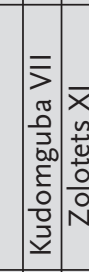 & 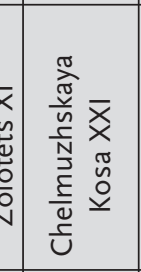 & 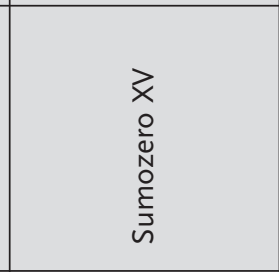 & 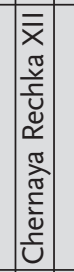 & 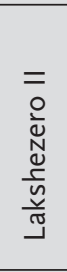 & 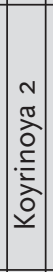 & 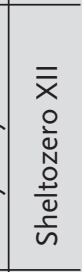 \\
\hline$\dot{\dot{c}}$ ż & & & $\stackrel{\bullet}{\circ}$ & $=$ & $=$ & $18 !$ & $1=1$ & 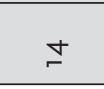 & $\mid \underset{\sim}{\mid \infty}=$ & $=1$ & $\stackrel{\sim}{N}$ & 이 & $m$ & & \\
\hline
\end{tabular}




\begin{tabular}{|c|c|c|c|c|c|}
\hline 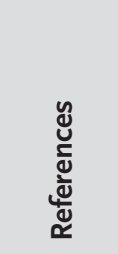 & 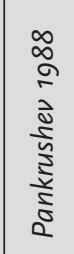 & $\begin{array}{l}\infty \\
\infty \\
2 \\
\frac{1}{5} \\
\frac{5}{5} \\
\frac{5}{5} \\
\frac{5}{0}\end{array}$ & 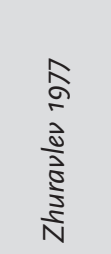 & 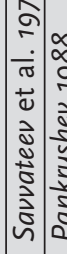 & 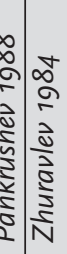 \\
\hline 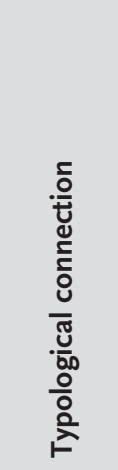 & 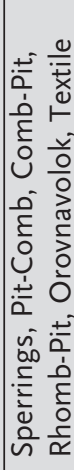 & 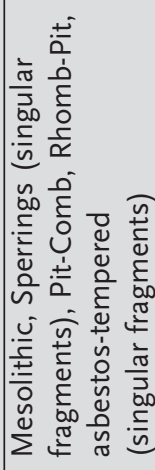 & 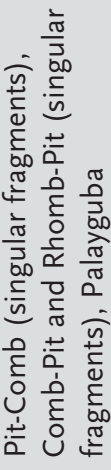 & 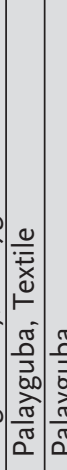 & 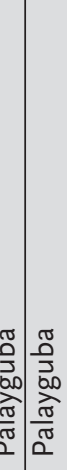 \\
\hline 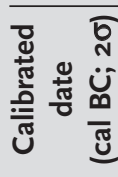 & 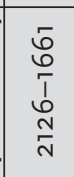 & $\begin{array}{l}\stackrel{+}{心} \\
\stackrel{1}{1} \\
\infty \\
\infty \\
\infty\end{array}$ & $\begin{array}{l}0 \\
\tilde{m} \\
\bar{J} \\
o \\
\sigma \\
\sigma\end{array}$ & 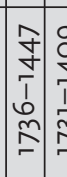 & 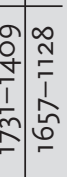 \\
\hline 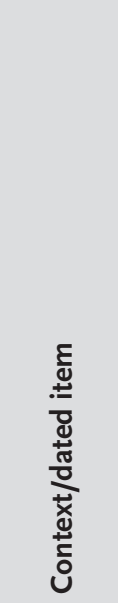 & 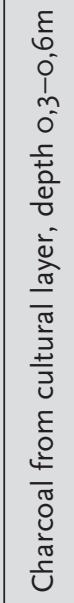 & 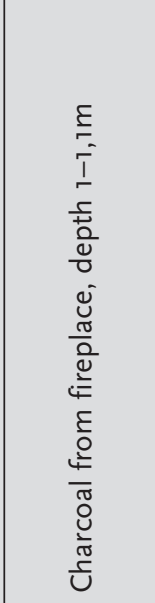 & 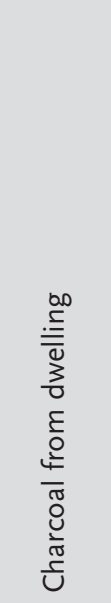 & 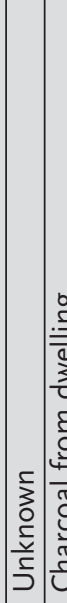 & 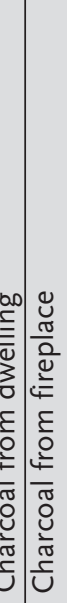 \\
\hline $\begin{array}{l}\frac{x}{0} \\
\underline{\underline{\Xi}} \\
\stackrel{0}{\Xi}\end{array}$ & $\underset{\substack{n \\
\stackrel{N}{1}}}{\stackrel{\infty}{\leftarrow}}$ & $\frac{O}{\frac{8}{d}}$ & 安 & 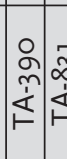 & 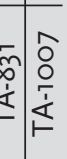 \\
\hline 离 & $\begin{array}{l}0 \\
\infty \\
+1 \\
0 \\
\tilde{n} \\
m\end{array}$ & $\begin{array}{l}0 \\
0 \\
+1 \\
0 \\
0 \\
\text { m. }\end{array}$ & 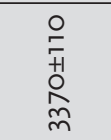 & 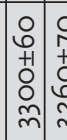 & 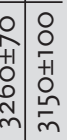 \\
\hline 离 & 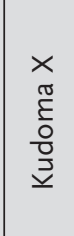 & 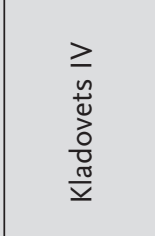 & 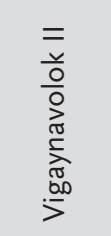 & 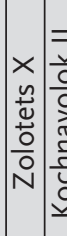 & 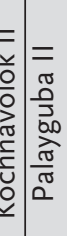 \\
\hline$\dot{\dot{z}}$ ¿ & $\mathrm{m}$ & $\stackrel{\circ}{ }$ & $\simeq$ & & $\left.\forall\right|^{n}$ \\
\hline
\end{tabular}




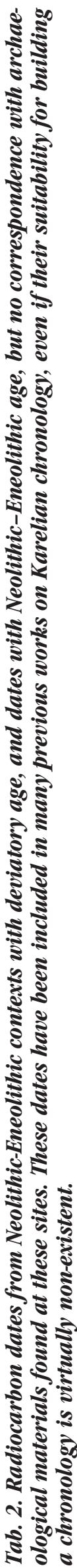

\begin{tabular}{|c|c|c|c|c|c|c|c|c|c|c|c|c|c|c|c|c|c|c|c|c|c|}
\hline 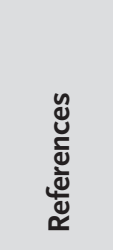 & 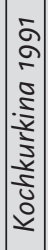 & 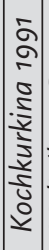 & 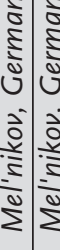 & 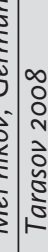 & 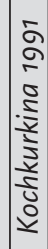 & 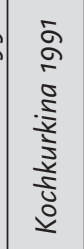 & 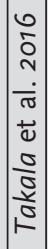 & 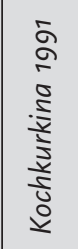 & 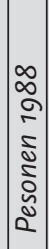 & 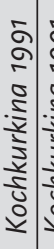 & & 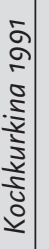 & 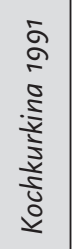 & 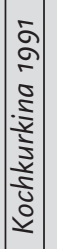 & 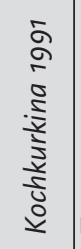 & 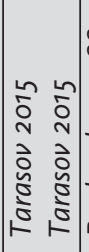 & 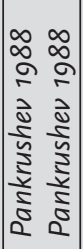 & $\begin{array}{c}\frac{7}{0} \\
2 \\
\frac{2}{2} \\
\frac{\partial}{2} \\
\frac{2}{2} \\
\frac{2}{2} \\
\frac{1}{N}\end{array}$ & 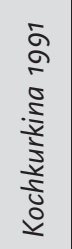 & 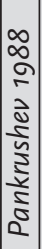 & 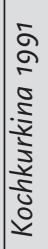 \\
\hline 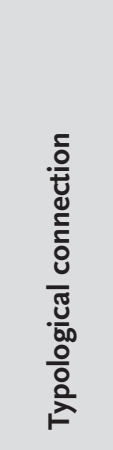 & 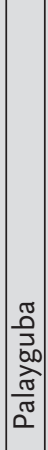 & & 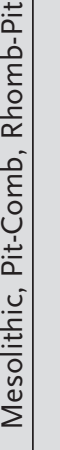 & 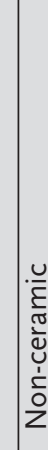 & 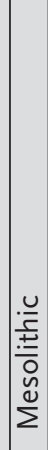 & 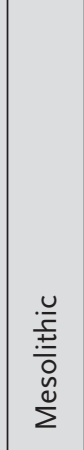 & 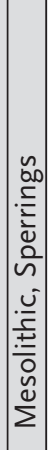 & 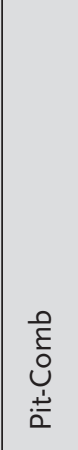 & \begin{tabular}{|l|}
$\frac{\pi}{0}$ \\
$\frac{d}{0}$ \\
$\frac{0}{0}$ \\
$\Sigma$ \\
\end{tabular} & 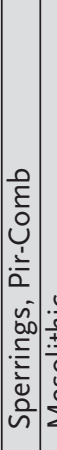 & 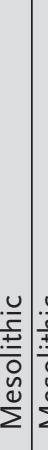 & 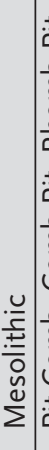 & 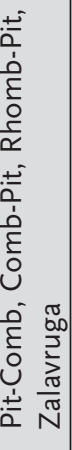 & 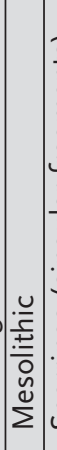 & 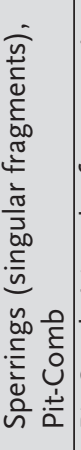 & 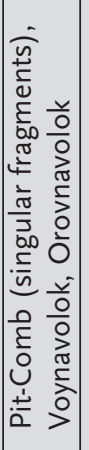 & 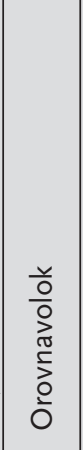 & : & 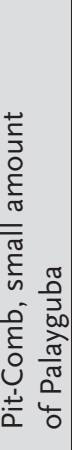 & 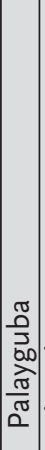 & 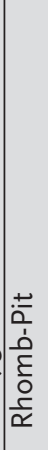 \\
\hline 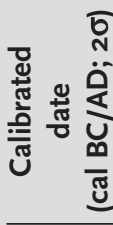 & 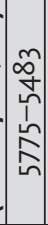 & 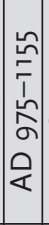 & 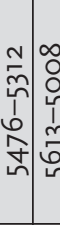 & 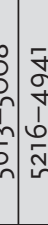 & 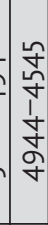 & 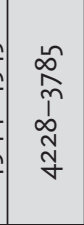 & $\begin{array}{c}\tilde{m} \\
\tilde{v} \\
\tilde{1} \\
\tilde{n} \\
\tilde{m} \\
\tilde{m}\end{array}$ & 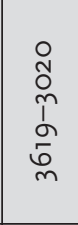 & $\begin{array}{l}N \\
\delta \\
\stackrel{N}{ } \\
1 \\
\sim \\
\tilde{m} \\
m\end{array}$ & $\mid \begin{array}{c}n \\
\tilde{\omega} \\
\text { N } \\
1 \\
\sim \\
\sim \\
m\end{array}$ & 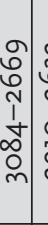 & 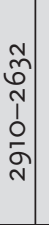 & $\begin{array}{l}\bar{\infty} \\
\stackrel{1}{1} \\
\tilde{N} \\
\text { v }\end{array}$ & $\begin{array}{c}\tilde{n} \\
\hat{1} \\
\frac{1}{N} \\
\hat{\alpha} \\
\bar{N}\end{array}$ & $\begin{array}{l}\overline{\tilde{n}} \\
\stackrel{1}{1} \\
\infty \\
\tilde{m}\end{array}$ & 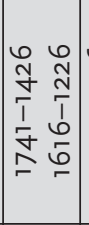 & 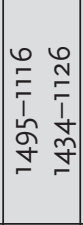 & 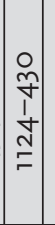 & 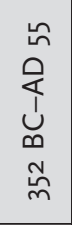 & 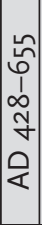 & $\begin{array}{l}5 \\
0 \\
1 \\
\text { 'n } \\
6 \\
0 \\
0\end{array}$ \\
\hline 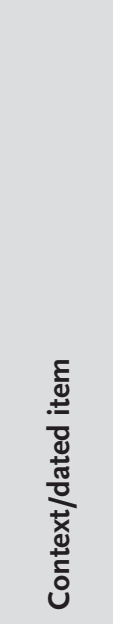 & 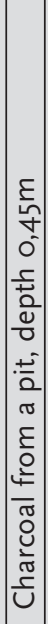 & 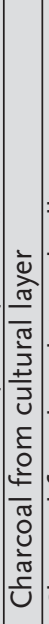 & 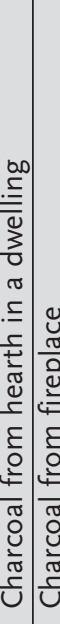 & 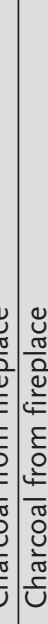 & 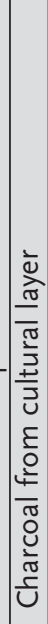 & 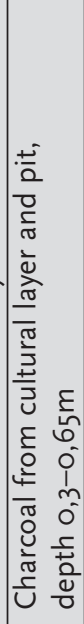 & 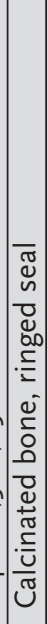 & 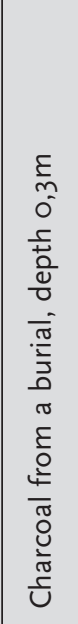 & 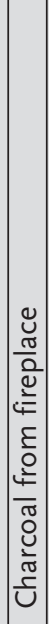 & 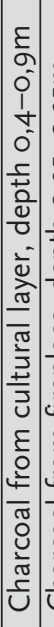 & 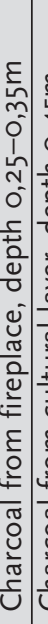 & 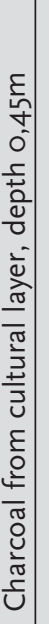 & 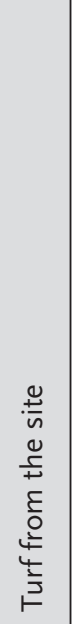 & 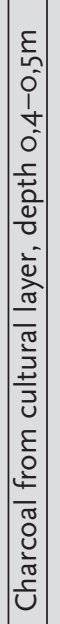 & 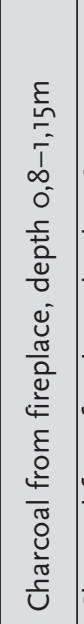 & 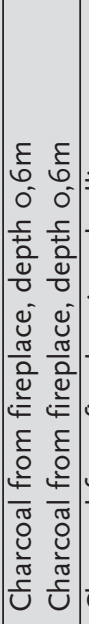 & 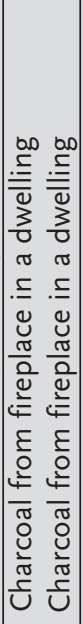 & 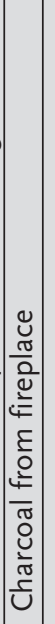 & 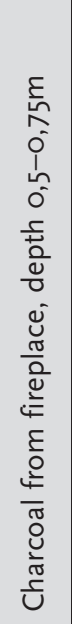 & 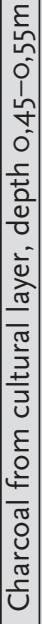 & 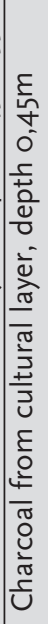 \\
\hline 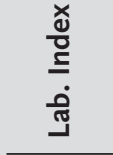 & 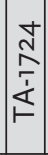 & $\mid \begin{array}{c}\stackrel{n}{N} \\
\stackrel{1}{\dot{\alpha}} \\
\vdash\end{array}$ & 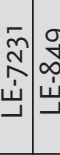 & 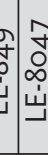 & $=\frac{9}{\hat{0}}$ & $\frac{\stackrel{\circ}{m}}{\frac{i}{i}}$ & 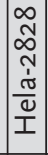 & $\frac{\stackrel{n}{\infty}}{\frac{\infty}{\dot{1}}}$ & $\begin{array}{l}0 \\
0 \\
0 \\
\vdots \\
\dot{1} \\
11\end{array}$ & $\begin{array}{c}\bar{m} \\
\bar{m} \\
\overline{1}\end{array}$ & $\begin{array}{l}\sigma \\
\tilde{n} \\
\\
⺊\end{array}$ & 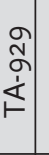 & 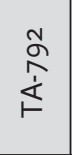 & $\begin{array}{l}m \\
0 \\
o \\
\dot{\alpha} \\
\vdash\end{array}$ & 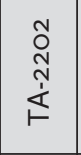 & 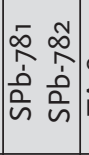 & 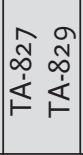 & 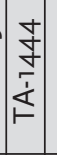 & 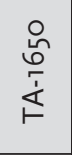 & 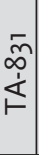 & 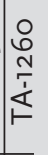 \\
\hline $\begin{array}{l}\stackrel{y}{\pi} \\
\stackrel{\tilde{J}}{0} \\
\dot{U}\end{array}$ & 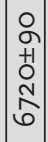 & $\mid \begin{array}{l}0 \\
+ \\
+1 \\
0 \\
0 \\
0 \\
-\end{array}$ & 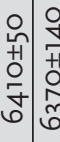 & 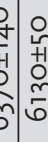 & $\left\{\begin{array}{l}0 \\
\infty \\
1 \\
0 \\
\infty \\
\infty \\
1\end{array}\right.$ & $\begin{array}{l}\circ \\
\stackrel{0}{+1} \\
0 \\
0 \\
\text { డn }\end{array}$ & $\begin{array}{c}1 \\
\tilde{n} \\
+1 \\
\infty \\
\infty \\
\forall\end{array}$ & \begin{tabular}{l}
0 \\
$\infty$ \\
+1 \\
0 \\
0 \\
\multirow{2}{+}{}
\end{tabular} & $\begin{array}{l}0 \\
6 \\
+1 \\
0 \\
0 \\
8 \\
7\end{array}$ & $\left|\begin{array}{c}0 \\
\infty \\
+1 \\
0 \\
0 \\
\end{array}\right|$ & 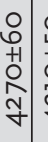 & $\begin{array}{l}0 \\
\stackrel{0}{1} \\
0 \\
\frac{1}{y} \\
y\end{array}$ & $\begin{array}{l}0 \\
\infty \\
+1 \\
\stackrel{1}{0} \\
6 \\
0\end{array}$ & $\begin{array}{l}0 \\
\infty \\
+1 \\
0 \\
0 \\
0 \\
m\end{array}$ & $\begin{array}{l}0 \\
\infty \\
+1 \\
\stackrel{m}{m} \\
\dot{m}\end{array}$ & $\left|\begin{array}{cc}0 & 0 \\
N & \infty \\
+1 & +1 \\
\infty & \infty \\
\infty & 0 \\
N & \sim \\
m & m\end{array}\right|$ & $\left|\begin{array}{ll}0 & 0 \\
N & 0 \\
+1 & 0 \\
0 & 0 \\
0 & 0 \\
0 & 0 \\
0 & 0 \\
1 & 0\end{array}\right|$ & 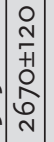 & $\begin{array}{l}0 \\
\text { O } \\
+1 \\
\infty \\
0 \\
\text { N }\end{array}$ & $\begin{array}{l}0 \\
0 \\
+1 \\
0 \\
0 \\
+ \\
+\end{array}$ & $\begin{array}{l}\text { 은 } \\
\stackrel{+1}{0} \\
\stackrel{0}{=} \\
=\end{array}$ \\
\hline$\stackrel{D}{5}$ & 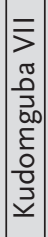 & & 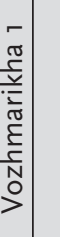 & $\begin{array}{l}\overline{\bar{x}} \\
x \\
\overline{\bar{d}} \\
\underline{\bar{u}} \\
\underline{y}\end{array}$ & 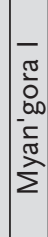 & $\begin{array}{l}\overline{\bar{x}} \\
\widetilde{\pi} \\
\overline{5} \\
v\end{array}$ & 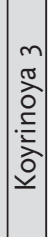 & 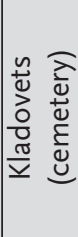 & 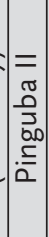 & $\mid \begin{array}{c}x \\
0 \\
0 \\
\frac{2}{N} \\
0 \\
\frac{1}{0} \\
0 \\
\bar{v}\end{array}$ & 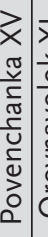 & $\begin{array}{l}\bar{x} \\
\text { ․ } \\
0 \\
0 \\
\text { o } \\
\frac{5}{3} \\
0 \\
0\end{array}$ & $\begin{array}{l}x \\
x \\
u \\
0 \\
\pm 0 \\
0 \\
0 \\
N\end{array}$ & 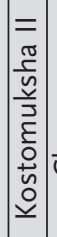 & 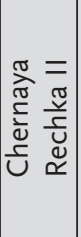 & 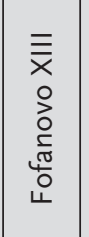 & 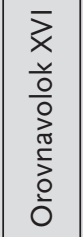 & 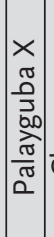 & 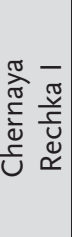 & 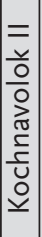 & 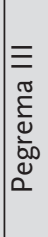 \\
\hline 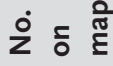 & & & +l & 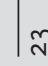 & la & N & in & 음 & $|\bar{N}|$ & & 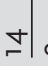 & & $\mp$ & $\sin$ & $\stackrel{\circ}{\circ}$ & $\stackrel{\sim}{\sim}$ & $\sigma$ & $|\mathbf{n}|$ & $\stackrel{ }{\circ}$ & -1 & \\
\hline
\end{tabular}

